\title{
Article
}

\section{The Freedom of Imagination: \\ Copyright's Constitutionality}

\author{
Jed Rubenfeld ${ }^{\dagger}$
}

\section{CONTENTS}

I. COPYRIGHT'S FIRST AMENDMENT IMMUNITY ............................ 5

II. THE SUPPOSED JUSTIFICATIONS OF COPYRIGHT'S FIRST AMENDMENT IMMUNITY ............................................... 12

A. Powers as Trumps................................................................. 12

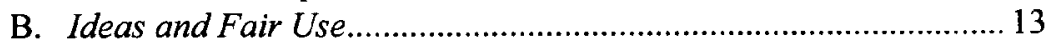

1. The Idea of Expression ..................................................... 13

2. Free Speech and Fair Use ........................................... 16

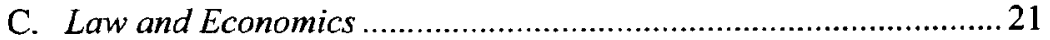

D. The Property Intuition......................................................... 24

1. Liability for Speaking ..................................................... 25

2. Private Power over Public Speech .................................. 27

III. THE FREEdOM OF IMAGINATION ................................................. 30

A. Giant-Sized First Amendment Theories ...................................... 30

B. The First Amendment Status of Art ....................................... 32

1. Art's Protection .............................................................. 32

2. Art, Democracy, and Expressive Autonomy ......................... 33

$\dagger$ Slaughter Professor of Law, Yale Law School. Special thanks to James Boyle, Yochai Benkler, Amy Chua, and David Lange. 


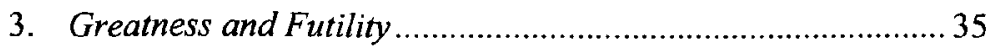

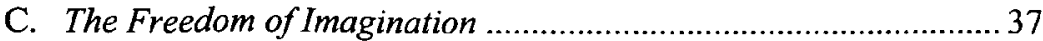

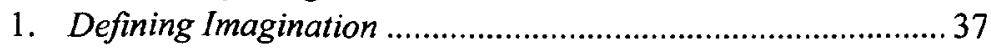

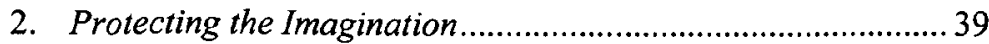

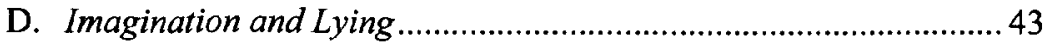

E. Imagination and Commercial Speech ...........................................46

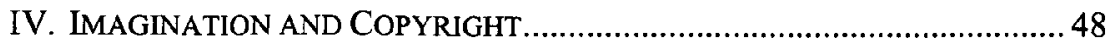

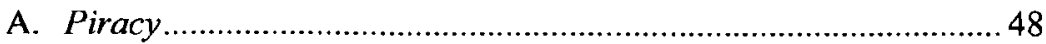

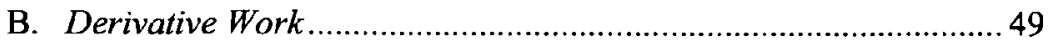

1. The Emergence of Derivative Works Rights........................... 49

2. How Current Law Blurs the Distinction Between

Reproductions and Derivative Works................................... 50

C. Constitutionalizing Copyright .....................................................53

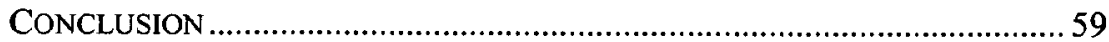


In some parts of the world, you can go to jail for reciting a poem in public without permission from state-licensed authorities. Where is this true? One place is the United States of America. ${ }^{1}$

Copyright law is a kind of giant First Amendment duty-free zone. It flouts basic free speech obligations and standards of review. ${ }^{2}$ It routinely produces results that, outside copyright's domain, would be viewed as gross First Amendment violations.

Outside of copyright, for example, a court order suppressing a book (especially in the form of a preliminary injunction) is called a "prior restraint," "the most serious and the least tolerable infringement on First Amendment rights." In copyright law, however, such orders are routine. ${ }^{4}$ Just last year, in a much-publicized case, a federal district court enjoined publication of The Wind Done Gone, the novel about a slave born on Gone with the Wind's Tara plantation. ${ }^{5}$ (Disclosure: I was counsel to Alice Randall, author of The Wind Done Gone, in this litigation.)

Or again, in 1995, a former member of the Church of Scientology posted on the Internet portions of the Church's "spiritual healing technology" materials, with the intention of exposing the Church as a "fraud." For this offense, police searched the individual's home for seven hours, seized books, and went through his personal computer files, copying some and erasing others, with the help of a "computer expert" provided by the Church. ${ }^{7}$ In the ensuing litigation, did the district court express concern about police officers assisting a "church" to suppress dissent? On the contrary, the court held that the defendant was likely guilty of copyright infringement and therefore issued a prior restraint "prohibiting any further copying" of Church materials.

1. A poem is of course copyrightable, see 17 U.S.C. $\$ \S 101,102(a)(1)(2000)$, and only the copyright owner has a right to "perform the copyrighted work publicly," id. § 106(4). To perform a work publicly means, among other things, "to recite" it "at a place open to the public or at any place where a substantial number of persons outside of a normal circle of a family and its social acquaintances is gathered." Id. $\S 101$. "Willful" copyright violations can be criminal offenses. Id. $\S 506$. I owe to Professor Lange the idea of highlighting copyright's application to the public "performance" of poetry.

2. See infra Part I.

3. Neb. Press Ass'n v. Stuart, 427 U.S. 539, 559 (1976); see, e.g., N.Y. Times Co. v. United States, 403 U.S. 713 (1971) (overturning on expedited review a preliminary injunction against the publication of the Pentagon Papers); Near v. Minnesota, 283 U.S. 697, 713 (1931).

4. See infra note 20.

5. See SunTrust Bank v. Houghton Mifflin Co., 136 F. Supp. 2d 1357 (N.D. Ga.), vacated, 252 F.3d 1165 (11th Cir.) (per curiam), order vacated and opinion substituted, 268 F.3d 1257 (11 th Cir. 2001). For further discussion of this case, see infra Part I.

6. See Religious Tech. Ctr. v. Netcom On-Line Communications Servs., Inc., 923 F. Supp. 1231, 1246, 1248 n. 19 (N.D. Cal. 1995).

7. Id. at 1240,1264 .

8. Id. at 1258 . 
What is particularly disturbing about these cases is that both district courts expressly declined to consider the defendants' First Amendment arguments. ${ }^{9}$ In this respect, the two cases were typical. Courts consistently hold that copyright does not have to answer to First Amendment scrutiny. "[C]opyrights," as the District of Columbia Circuit recently put it, "are categorically immune from challenges under the First Amendment." 10

It is time to put copyright on trial. The familiar explanations of copyright's insulation from the First Amendment are wholly inadequate. A new First Amendment analysis of copyright is needed.

This means, however, that we also need an account of the First Amendment status of art and entertainment. Art and entertainment are central to (although not exhaustive of the business of copyright; how central are they to the First Amendment? A painting by Pollock is "unquestionably shielded" by current free speech law," but what makes it so is less clear. Are video games-typical subjects of copyright lawsimilarly protected? What does their protectedness depend on, and would the level of protection change if they qualified as "art"? Thinking through copyright's constitutionality requires answers to these questions.

Contemporary First Amendment scholarship offers two principal accounts of art's protection: one based on art's contribution to democracy, the other based on art's contribution to individual self-realization. ${ }^{12}$ Both approaches are driven by preconceptions of First Amendment theory; neither is satisfactory. The first paints art too politically, the second too narcissistically. It is no coincidence that a free speech jurisprudence lacking a good account of art's protection also lacks an appropriate framework within which to evaluate copyright.

I will suggest that the constitutional protection of art is best understood through a principle I will call the freedom of imagination. Under this freedom, no one can be penalized for imagining or for communicating what he imagines. Nor can a person be required to obtain permission from anyone in order to exercise his imagination. Copyright, I will argue, must answer to this freedom.

Part I of this Article describes copyright's conflicts with the First Amendment and shows how, notwithstanding these conflicts, courts refuse to subject copyright to independent First Amendment review. Part II addresses the most common explanations of copyright's First Amendment

9. See infra Part I.

10. Eldred v. Reno, 239 F.3d 372, 375 (D.C. Cir. 2001), cert. granted sub nom. Eldred v. Ashcroft, 122 S. Ct. 1062 (2002). (1995)

11. Hurley v. Irish-Am. Gay, Lesbian \& Bisexual Group of Boston, Inc., 515 U.S. 557, 569

12. See infra Subsection III.B.2. 
immunity. These explanations are, for the most part, standard fare in the literature. None of them, however, is remotely adequate.

Part III elaborates the freedom of imagination, defining, defending, and delimiting it. This freedom, I will suggest, not only best captures the First Amendment's protection of art, but also underlies a number of other paradigmatic First Amendment protections as well.

Part IV measures copyright against this freedom. I argue that copyright's core prohibition against piracy is consistent with the freedom of imagination, but that a good deal of copyright law outside this core is not. In particular, the freedom of imagination calls into question the enormous and growing set of prohibitions imposed by modern copyright law on socalled "derivative" works. I conclude that copyright's prohibition of unauthorized derivative works is unconstitutional, but that it could be saved if its regime of injunctions and damages were replaced by an action for profit allocation.

\section{COPYRIGHT'S FIRST AMENDMENT IMMUNITY}

Copyright law blithely ignores at least three basic principles of free speech jurisprudence that elsewhere go without saying. First, a core doctrinal premise of modern First Amendment law is that "content-based speech restriction[s]" must satisfy "strict scrutiny."13 "If a statute regulates speech based on its content, it must be narrowly tailored to promote a compelling Government interest. If a less restrictive alternative would serve the Government's purpose, the legislature must use that alternative." 14

Is copyright law "content-based"? If a speech regulation is contentbased when, "on its face, [it] discriminates based on content,"15 or imposes burdens "based on the content of the speech," clearly content-based in at least some of its applications. You cannot begin to tell if The Wind Done Gone infringes without reading it, understanding it, and comparing its content to that of Gone with the Wind. ${ }^{17}$ Is copyright law narrowly tailored to further a compelling governmental interest, and is it the

13. United States v. Playboy Entm't Group, Inc., 529 U.S. 803, 813 (2000) ("Since $\$ 505$ is a content-based speech restriction, it can stand only if it satisfies strict scrutiny.").

14. Id. (citation omitted). There is no doctrinal difference between content-based "prohibition[s]" and content-based "regulation[s]" or "burdens." Id. at 812.

15. Turner Broad. Sys., Inc. v. FCC, 512 U.S. 622, 642-43 (1994).

16. Forsyth County v. Nationalist Movement, 505 U.S. 123, 134 (1992) (holding that a parade- and assembly-permitting scheme imposing higher fees "based on the content of the speech" was content-based).

17. "Copyright liability turns on the content of what is published." Mark A. Lemley \& Eugene Volokh, Freedom of Speech and Injunctions in Intellectual Property Cases, 48 DUKE L.J. 147,186 (1998). 
least restrictive means of doing so? No court has asked, much less answered, these questions. ${ }^{18}$

Second, no First Amendment principle runs deeper than the bar against prior restraints, considered so "absolute" that it applies even to classified documents potentially threatening national security. ${ }^{19}$ Yet in copyright cases, as noted above, courts issue prior restraints-prepublication injunctions, including preliminary injunctions-all the time. ${ }^{20}$

Third, outside of copyright law, a speech restriction based not merely on content, but on viewpoint, is considered virtually unconstitutional per $\mathrm{se}^{21}$ "The restriction must not discriminate against speech on the basis of viewpoint." $" 22$ (Viewpoint discrimination is so broadly condemned that it is said to be impermissible even in a nonpublic forum or within a category of otherwise unprotected speech. ${ }^{23}$ ) If Congress prohibited all speech concerning the President except speech "critical" of him, courts would

18. Sadly for free speech law, that a regulation is based on content does not always mean it is content-based, see City of Renton v. Playtime Theatres, Inc., 475 U.S. 41,47 (1986) (Rehnquist, J.) (holding that a regulation of "adult" movies was "content-neutral" because the regulation was "aimed" at "secondary effects" of speech), and commentators sometimes use a Renton-like argument to say that copyright is content-neutral, see, e.g., Neil Weinstock Netanel, Locating Copyright Within the First Amendment Skein, 54 STAN. L. REV. 1, 47-55 (2001) (stressing copyright's content-neutral aims). My own view is that Renton, as limited by later cases, see, e.g., Boos v. Barry, 485 U.S. 312, 320-21 (1988) (plurality opinion), does not apply to copyright and is, in any event, an analytical embarrassment. But the essential point is that courts have not asked these questions about copyright law. I argue below that copyright law should not be regarded as content-based in some of its applications. See infra Section IV.A.

19. See N.Y. Times Co. v. United States (the Pentagon Papers Case), 403 U.S. 713, 725-26 (1971) (Brennan, J., concurring) ("[T]he First Amendment tolerates absolutely no prior judicial restraints of the press predicated upon surmise or conjecture that untoward consequences may result."). Hostility to prior restraints on publication famously dates back to JOHN MILTON, Areopagitica: A Speech for the Liberty of Unlicensed Printing, in AREOPAGITICA AND OTHER POLITICAL WRITINGS OF JOHN MILTON 3 (Liberty Fund 1999) (1644). See also 4 William BLACKSTONE, COMMENTARIES *151 ("The liberty of the press ... consists in laying no previous restraints upon publications.").

20. See Lemley \& Volokh, supra note 17 , at $158-59$. Copyright law actually favors prior restraints, by presuming "irreparable injury" in infringement cases and thereby almost "automatically" triggering an injunction upon proof of a likelihood of success on the merits. See, e.g., Am. Direct Mktg., Inc. v. Azad Int'l, Inc., 783 F. Supp. 84, 96 (E.D.N.Y. 1992) (noting that in the Second and Ninth Circuits, "a finding of likelihood of success on the merits automatically triggers a preliminary injunction, and failure to issue one is reversible error if the validity of the copyright and existence of copying are not at issue").

21. See, e.g., KATHLEEN M. SUlLIVAN \& Gerald GUNTHER, FirSt AMENDMENT LAW 193 (1999) (noting that viewpoint discrimination has been treated as "the paradigm violation of the First Amendment").

22. Good News Club v. Milford Cent. Sch., 533 U.S. 98, 106 (2001); see also Rosenberger v. Rector \& Visitors of Univ. of Va., 515 U.S. 819, 828 (1995) ("It is axiomatic that the government may not regulate speech based on its substantive content or the message it conveys.").

23. See, e.g., R.A.V. v. City of St. Paul, 505 U.S. 377,384 (1992) ("[T]he government may proscribe libel; but it may not ... proscrib[e] only libel critical of the government."); Comelius v. NAACP Legal Def. \& Educ. Fund, Inc., 473 U.S. 788, 806 (1985) (stating that regulations on speech in "a nonpublic forum can be based on subject matter ... so long as the distinctions drawn are reasonable . . . and are viewpoint-neutral"). 
almost certainly deem the law viewpoint-discriminatory and strike it down. Yet in copyright cases, courts are frequently called upon to enjoin speech that borrows from a copyrighted work unless it is "critical" of that work. ${ }^{24}$ Isn't this plainly a restriction of speech "on the basis of viewpoint"? Again, no court has asked the question.

These conflicts between copyright and First Amendment doctrine do not prove that copyright is unconstitutional. After all, copyrighted speech is not the only speech denied full First Amendment protection. But copyright is the exception least theorized and most systematically suppressed.

The Supreme Court has long recognized a number of "claśses" of unprotected speech, such as obscenity, libel, incitement, "fighting words," or, in earlier decades, profanity and commercial advertising. ${ }^{25}$ But each entry on this "well-defined and narrowly limited"26 list-a list on which copyrighted speech has never even registered-has been subjected to intensive First Amendment scrutiny. Over time, in each case, the Court has either reversed itself and granted protection, ${ }^{27}$ or has developed a network of special First Amendment rules closely trammeling the state's ability to regulate the speech in question. ${ }^{28}$

Not so with copyright. Despite the voluminous case law, there is astonishingly little contemporary judicial discussion of copyright's First Amendment implications. Copyright proceeds as if possessed of a magic free speech immunity, with most courts, including the Supreme Court, explicitly declining to subject copyright to any independent First Amendment review. ${ }^{29}$

24. See, e.g., Campbell v. Acuff-Rose Music, Inc., 510 U.S. 569, 578 (1994) (analyzing whether the defendant's song was sufficiently "critical" of the copyrighted song on which it was based). The issue of whether an allegedly infringing work is a "criticism" of the copyrighted work arises under the fair use defense, codified at 17 U.S.C. $\$ 107$ (2000). The fair use doctrine is discussed further below. See infra Subsection II.B.2.

25. See, e.g., Valentine v. Chrestensen, 316 U.S. 52, 54 (1942) (stating that the First Amendment imposes no "restraint on government as respects purely commercial advertising"); Chaplinsky v. New Hampshire, 315 U.S. 568, 571-72 (1942) ("There are certain well-defined and narrowly limited classes of speech, the prevention and punishment of which have never been thought to raise any Constitutional problem. These include the lewd and the obscene, the profane, the libelous, and ... 'fighting words."').

26. Chaplinsky, 315 U.S. at 571.

27. See Va. State Bd. of Pharmacy v. Va. Citizens Consumer Council, 425 U.S. 748 (1976) (holding commercial speech protected); Cohen v. California, 403 U.S. 15 (1971) (holding that "Fuck the Draft" was protected speech).

28. See, e.g., Miller v. California, 413 U.S. 15 (1973) (obscenity); Gooding v. Wilson, 405 U.S. 518 (1972) (fighting words); Brandenburg v. Ohio, 395 U.S. 444 (1969) (incitement); N.Y. Times Co. v. Sullivan, 376 U.S. 254 (1964) (libel).

29. See, e.g., Harper \& Row, Publishers, Inc. v. Nation Enters., 471 U.S. 539, 556, 560 (1985); Eldred v. Reno, 239 F.3d 372, 375 (D.C. Cir. 2001), cert. granted sub nom. Eldred v. Ashcroft, 122 S. Ct. 1062 (2002). Although copyright law is arguably the country's most sweeping and important regulation of speech, its treatment in leading casebooks is typically limited to a single paragraph or footnote. See, e.g., SULLIVAN \& GUNTHER, supra note 21 , at 88 - 
But the field of intellectual property is changing today. It is enjoying unprecedented growth, in both importance and scope. As a result, there is renewed interest, at least academically, in copyright's long-suppressed confrontation with the First Amendment. ${ }^{30}$ In the case law, however, this confrontation remains evanescent, almost but never quite taking place.

Consider the Wind Done Gone litigation. ${ }^{31}$ For legal purposes, the basic facts of the case were straightforward. The Wind Done Gone plainly took a host of characters, settings, and plotlines from Gone with the Wind (although the former also created a new protagonist and told a new, postCivil War story occurring after the events described in the latter) ${ }^{32}$ On the other hand, the actual text of The Wind Done Gone repeated very little of the actual text of Gone with the Wind (there was little literal copying). ${ }^{33}$ Finally, whatever one thinks of the literary merits of this genre, ${ }^{34}$ The Wind

89; William W. Van Alstyne, First amendment: Cases and Materials $213 \mathrm{n} .97(2 \mathrm{~d}$ ed. 1995).

30. Professors Boyle and Benkler have been especially important in this movement. See, e.g., Yochai Benkler, Free as the Air to Common Use: First Amendment Constraints on Enclosure of the Public Domain, 74 N.Y.U. L. REV. 354 (1999); James Boyle, The First Amendment and Cyberspace: The Clinton Years, 63 LAW \& CONTEMP. PROBS. 337 (2000). For other excellent treatments, see Stephen Fraser, The Conflict Between the First Amendment and Copyright Law and Its Impact on the Internet, 16 CARDOZO ARTS \& ENT. L.J. 1 (1998); Lemley \& Volokh, supra note 17; Netanel, supra note 18; Rebecca Tushnet, Copyright as a Model for Free Speech Law: What Copyright Has in Common with Anti-Pornography Laws, Campaign Finance Reform, and Telecommunications Regulation, 42 B.C. L. REV. 1 (2000); and Hannibal Travis, Comment, Pirates of the Information Infrastructure: Blackstonian Copyright and the First Amendment, 15 BERKELEY TECH. L.J. 777 (2000).

31. SunTrust Bank v. Houghton Mifflin Co., 136 F. Supp. 2d 1357 (N.D. Ga.), vacated, 252 F.3d 1165 (11th Cir.) (per curiam), order vacated and opinion substituted, 268 F.3d 1257 (11th Cir. 2001).

32. Place names and character names are altered in The Wind Done Gone, but just barely (Tara, for example, becomes "Tata"). See SunTrust Bank, 268 F.3d at 1267 (stating that The Wind Done Gone "appropriates numerous characters, settings, and plot twists" from Gone with the Wind "transparent[ly] renam[cd]"). The protagonist is supposed to be Scarlett's halfsister, the daughter of Scarlett's father and the house slave "Mammy." See ALICE RANDALL, THE WIND DONE GONE 1 (2001).

33. In papers submitted to the district court, the plaintiff was able to identify three instances of what it called "stolen verbatim dialogue" out of over a thousand collective pages. See Memorandum of Law in Support of Plaintiff's Motion for a Temporary Restraining Order and Preliminary Injunction at 13, SunTrust Bank, 136 F. Supp. 2d 1357 (No. 01-701). One of the three examples was this: Gone with the Wind's last line, "[T] to have been "stolen verbatim" by The Wind Done Gone's last line, "For all those we love for whom tomorrow will not be another day, we send the sweet prayer of resting in peace." Id.

34. Retellings from a different character's perspective are not a literary taboo; they are closer to a literary cliché. Well-known examples include Tom Stoppard's play on Hamlet, Rosencrantz and Guildenstern Are Dead, and Jean Rhys's Wide Sargasso Sea, a retelling of Jane Eyre. While Henry Fielding's 1741 Shamela used the perspectival-shift device only glancingly to parody Samuel Richardson's phenomenally popular Pamela, Fielding's Joseph Andrews, one of the first great comic novels in English, is the story of Pamela's supposed brother, and it refers to a number of Pamela's persons and events from this brother's point of view. HENRY FIELDING, JOSEPH ANDREWS (1742), reprinted in JOSEPH ANDREWS AND SHAMELA (Martin C. Battestin ed., Riverside Press 1961); HENRY FIELDING, SHAMELA (1741), reprinted in JOSEPH ANDREWS AND SHAMELA, supra. 
Done Gone's "political" point was clear enough: to expose the erasure of black subjectivity in Gone with the Wind, to combat its racial stereotypes, and to impugn its nostalgic, romantic vision of the Old South. ${ }^{35}$

The district court granted a preliminary injunction, calling The Wind Done Gone a "sequel" to Gone with the Wind, and therefore an infringement of the copyright holder's exclusive right to publish "derivative works." ${ }^{36}$ Which is to say: The court ordered what would, outside of copyright law, be regarded as a prior restraint. The First Amendment did not go unmentioned in the district court's thirty-page opinion. On page 29, in a single paragraph and footnote, the judge raised and disposed of the First Amendment with the proposition, for which ample authorities were cited, that "[i]njunctive relief may be freely granted by the courts in order to prevent infringement of a copyright., 37

The Eleventh Circuit reversed. Unusually, it did so from the bench, issuing a terse order declaring the injunction to be a "manifest," "unlawful prior restraint in violation of the First Amendment."38 Still more unusually, the circuit judges later vacated their own order. ${ }^{39}$ In the later opinion, the injunction is no longer called a "manifest" First Amendment violation. Rather, the opinion expresses "First Amendment concerns," while holding that the plaintiff had failed to show irreparable harm or a likelihood of prevailing on its copyright claim. ${ }^{40}$

Thus the confrontation between copyright law and the First Amendment briefly flared, but did not quite materialize. For the district court, this confrontation was invisible; the judge saw no First Amendment difficulty at all. The appellate court saw the difficulty, but ultimately decided the case within the confines of copyright doctrine, rather than meeting the conflict head on.

The failure to confront copyright's tensions with the First Amendment has disturbing consequences. A vivid example can be found in Religious

35. Mitchell's book contains numerous racist passages. Particularly favored are comparisons of blacks to monkeys and apes. See, e.g., MARGARET MITCHELL, GONE WITH THE WIND 390 (Scribner 1996) (1936) ("How stupid negroes were!"); id. at 407 ("niggery smell . . increased her nausea"); id. at 447 ("Negroes were provoking sometimes and stupid and lazy, but there was loyalty in them that money couldn't buy, a feeling of oneness with their white folks"); id. at 55152 ("insolent grins," "black apes"); id. at 597 ("lazy and shiftless"); $i d$. at 611 ("creatures of small intelligence," "[1]ike monkeys"); id. at 838 ("negroes sat in the legislature where they spent most of their time eating goobers").

36. SunTrust Bank, 136 F. Supp. $2 \mathrm{~d}$ at 1385-86.

37. Id. at 1385 n.21.

38. SunTrust Bank v. Houghton Mifflin Co., 252 F.3d 1165, 1166 (11th Cir.) (per curiam), order vacated and opinion substituted, 268 F.3d 1257 (11 th Cir. 2001).

39. SunTrust Bank, 268 F.3d at 1277.

40. Id. at 1276. Still, the Eleventh Circuit's treatment of the free speech issues in SunTrust Bank is far superior to that of most other courts in copyright cases, and the opinion, in its "conclusion" section, does refer to the preliminary injunction as a "prior restraint." Id. at 1277 . 
Technology Center, the Church of Scientology case mentioned earlier. ${ }^{41}$ This was the case in which a prior restraint, prohibiting dissemination of Church materials, followed upon a police search of the defendant's home and personal computer.

Religious Technology Center is a bracing case from a First Amendment perspective. To put its facts into a larger constitutional context, one might (anachronistically) imagine the police combing through private homes for copies of the Bible, and threatening to arrest anyone found distributing that work, on the ground that the Bible infringed copyrights in the Old Testament. In Religious Technology Center, a "church" and police officers took concerted action with the effect of suppressing religious dissent. One might have thought that such a case raised First Amendment problems of a high order.

Yet the court in Religious Technology Center saw at most a Fourth Amendment problem. ${ }^{42}$ In a sense, the court's reaction was natural; it was the product of copyright's longstanding First Amendment immunity combined with the contemporary inclination, when dealing with the constitutionality of police searches and seizures, to see only Fourth Amendment issues. We tend to forget the connection between the Fourth Amendment's ban on "general warrants"-which authorized indiscriminate searches of individuals' homes, papers, and effects-and the First Amendment's protection of religious and political dissent. Historically, general warrants were condemned in no small part because of their role in suppressing dissent and in enabling the English system of prior restraints. ${ }^{43}$ "In sixteenth- and seventeenth-century England, general warrants were the very devices by which various schemes of prior restraint and printer licensing were enforced." 44 While the district court in Religious Technology Center found the search (and the search warrant) to have been overbroad, ${ }^{45}$ the court failed to draw any connections between this unconstitutionality and the First Amendment aspects of the case. Without even acknowledging the extraordinary constitutional delicacy of a case combining police searches under "church" supervision, seizure of religious materials, and prior restraints on religious dissent, the district court dismissed the

41. Religious Tech. Ctr. v. Netcom On-Line Communication Servs., Inc., 923 F. Supp. 1231 (N.D. Cal. 1995).

42. See id. at 1263-64.

43. See NELSON B. LASSON, THE HISTORY AND DEVElopMENT OF THE FOURTH AMENDMENT TO THE UNTTED STATES CONSTITUTION 24-50 (1937); STEPHEN A. SALTZBURG \& DANIEl J. CAPRA, AMERICAN CRIMINAl Procedure 56-57 (4th ed. 1992); 3 JOSEPH STORY, COMMENTARIES ON THE CONSTITUTION OF THE UNITED STATES $§ 1895$ (photo. reprint 1991) (Boston, Hilliard, Gray \& Co. 1833).

44. AKHIL REED AMAR, THE BILL OF RIGHTS: CREATION AND RECONSTRUCTION 72 (1998).

45. Religious Tech. Ctr., 923 F. Supp. at 1263-64. 
defendant's "First Amendment concerns" in a single paragraph ${ }^{46}$ As in the Wind Done Gone case, the district court explained that copyright claims were not subject to independent First Amendment review. ${ }^{47}$

Copyright's insulation from First Amendment review is made particularly awkward by the dramatic enlargement of copyright's coverage over the years. Copyrights used to bar only copying, understood to mean a literal reprinting or reproduction of the entire copyrighted work. ${ }^{48}$ Translating a book, for example, or even abridging it, did not count as infringement. ${ }^{49}$ Nor was it possible to violate a copyright by saying anything; the early statutes barred only the making or selling of printed reproductions. ${ }^{50}$ Times, however, have changed. ${ }^{51}$ Today, if you recite in public a few lines from Martin Luther King's famous I Have a Dream speech, you risk liability for copyright infringement. ${ }^{52}$

We should not act as if it goes without saying that the federal government can prohibit you from reciting a poem or from invoking King's words in public. Or that, in order to say those words, you might need someone's permission. Or that a judge in the United States in 2001, without any constitutional compunction-without even acknowledging any First Amendment difficulties-could suppress a book challenging one of the nation's iconic cultural-historical narratives.

On what ground are copyrights supposed to be "categorically immune ${ }^{, 53}$ from First Amendment challenge? The first task is to address

46. Id. at $1257-58$.

47. Id.

48. See infra Subsection IV.B.1.

49. See, e.g., Lawrence v. Dana, 15 F. Cas. 26, 59 (C.C.D. Mass. 1869) (No. 8136) (abridgment); Stowe v. Thomas, 23 F. Cas. 201 (C.C.E.D. Pa. 1853) (No. 13,514) (translation); see also infra Subsection IV.B.1

50. The first American copyright statute applied only to "printing, reprinting, publishing and vending" copies of any "map, chart, book or books." Act of May 31, 1790, ch. 15, $\S 1,1$ Stat. 124, 124 (repealed 1802). Musical compositions were added in 1831, but still the copyright extended only to "printing, reprinting, publishing, and vending" copies of the sheet music, not to performing the work. Act of Feb. 3, 1831, ch. 16, § 1, 4 Stat. 436, 436.

51. The first "performance right"-applicable only to dramatic works--was added in 1856. Act of Aug. 18, 1856, ch. 169, 11 Stat. 138, 138-39. The first "derivative works rights" were granted in 1870 , when authors were permitted to "reserve the right to dramatize or to translate their own works." Act of July 8,1870 , ch. $230, \S 86,16$ Stat. 198, 212. Today, copyright holders have a broad, exclusive performance right as well as the exclusive right to "prepare derivative works based upon the copyrighted work." 17 U.S.C. $§ 106(2)$, (4) (2000); see also infra Subsection IV.B.1.

52. Cf. Estate of Martin Luther King, Jr., Inc. v. CBS, 194 F.3d 1211 (11th Cir. 1999) (reversing dismissal of plaintiff's copyright suit challenging a CBS documentary that showed CBS footage of King's 1963 speech); Martin Luther King, Jr. Ctr. for Soc. Change, Inc. v. Am. Heritage Prods., Inc., 508 F. Supp. 854, 861 (N.D. Ga. 1981) (finding "likely" infringement in the use of twelve sentences from the King speech), rev'd on other grounds, 694 F.2d 674 (11th Cir. 1983).

53. Eldred v. Reno, 239 F.3d 372, 375 (D.C. Cir. 2001), cert. granted sub nom. Eldred v. Ashcroft, 122 S. Ct. 1062 (2002). 
the various arguments purporting to justify copyright's First Amendment immunity.

\section{THE SUPPOSED JUSTIFICATIONS OF COPYRIGHT'S FIRST AMENDMENT IMMUNITY}

There are four principal explanations of copyright's insulation from First Amendment review. The first relies on Congress's express constitutional power to grant copyrights. The second argues that two copyright doctrines-the idea/expression distinction and the fair use doctrine-already handle free speech concerns. The third makes an economic argument: that copyrights increase overall speech production. The fourth holds that there is no free speech right to steal someone else's property. I discuss each in turn.

\section{A. Powers as Trumps}

The Constitution empowers Congress to "secur[e] for limited Times to Authors ... the exclusive Right to their... Writings." ${ }^{54}$ This textual authorization, it might be argued, assures copyright's constitutionality. How could copyright be unconstitutional when it is the "congressional implementation of a constitutional directive" ${ }^{55}$

There is a good reason why this argument is rarely advanced. It misunderstands the basic structure of American constitutional law. Specifically, it gets backward the relationship between powers and rights.

Just because a law passed by Congress falls within the terms of an Article I power, the law is not thereby exempt from the Bill of Rights. A federal law prohibiting "the sale of the Bible across state lines" would regulate commerce among the states, but it would still be unconstitutional. Rights trump powers, not vice versa.

The exclusive rights clause of Article I does not create constitutional rights that courts may "balance" against First Amendment rights. Rather, the clause creates a congressional power: the power to enact statutory copyrights, patents, and other limited intellectual property monopolies. This power Congress may or may not choose to exercise, but like any other Article I power, it is undoubtedly subordinate to the First Amendment.

54. U.S. CONST. art. I, $\S 8$, cl. 8.

55. Cable/Home Communication Corp. v. Network Prods., Inc., 902 F.2d 829, 849 (1 lth Cir. 1990); cf. Religious Tech. Ctr. v. Netcom On-Line Communication Servs., Inc., 923 F. Supp. 1231, 1258 (N.D. Cal. 1995) (describing, incorrectly, "the rights of copyright holders" as "guaranteed by the Constitution, U.S. Const. art. I, § 8"). 
The exclusive rights clause is not wholly irrelevant to copyright's First Amendment status. It provides a reason to reject interpretations of the First Amendment that would block copyright altogether (just as the post offices clause $^{56}$ provides a reason to reject interpretations of the First Amendment that would block a federal postal service altogether). At most, however, this reasoning shows only that some copyright legislation is constitutional. It does not prove that all copyright legislation-or that any of the copyright law we currently have-is constitutional.

Against a claim that a federal statute violates the Bill of Rights, it is never an answer that the statute falls within the terms of an Article I power. Congress must act within the ambit of its Article I powers, and it must not violate constitutional rights.

\section{B. Ideas and Fair Use}

The far commoner and stronger defense of copyright's insulation from First Amendment scrutiny is that copyright law already handles all pertinent free speech concerns through its own doctrinal rules. Two copyright doctrines in particular are said to be decisive: (1) the idea/expression distinction and (2) the fair use doctrine.

\section{The Idea of Expression}

Copyright, it has been said a thousand times, "protects only expression, and not ideas." 57 The claim that a law restricts "only expression" might not seem a promising line of First Amendment defense, yet courts and commentators have repeatedly relied on the idea/expression distinction to explain why copyright poses no serious free speech problems. "Copyright

56. See U.S. CONST. art. I, $\S 8$, cl. 7 (granting Congress the power to "establish Post Offices and post Roads").

57. Schoolhouse, Inc. v. Anderson, 275 F.3d 726, 728 (8th Cir. 2002); see also 17 U.S.C. § 102(b) (2000) ("In no case does copyright protection for an original work of authorship extend to any idea ...., regardless of the form in which it is described, explained, illustrated, or embodied in such work."); Mazer v. Stein, 347 U.S. 201,217 (1954) ("[P]rotection is given only to the expression of the idea-not the idea itself."); Foad Consulting Group, Inc. v. Musil Govan Azzalino, $270 \mathrm{~F} .3 \mathrm{~d} 821,829 \mathrm{n} .13$ (9th Cir. 2001) ("Copyright law protects only the expression of ideas, not ideas themselves.").

58. See, e.g., Harper \& Row, Publishers, Inc. v. Nation Enters., 471 U.S. 539, 556 (1985); Zacchini v. Scripps-Howard Broad. Co., 433 U.S. 562, 578 n.13 (1977) ("[C]opyright law does not abridge the First Amendment because it does not restrain the communication of ideas or concepts."); Eldred, 239 F.3d at 376; 1 MELVILLE B. NIMMER \& DAVID NIMMER, NIMMER ON COPYRIGHT § 1.10[B][2] (2001) [hereinafter NIMMER]; Robert Denicola, Copyright and Free Speech: Constitutional Limitations on the Protection of Expression, 67 CAL. L. REV, 283, 289-99 (1979). It is similarly said that copyright does not protect "facts," which is also supposed to avoid First Amendment difficulties. See, e.g., Harper \& Row, 471 U.S. at 556. 
laws are not restrictions on freedom of speech," to quote the Supreme Court, because "copyright protects only form of expression and not the ideas expressed." 59

What does it mean to distinguish ideas from expression? One way to express the basic concept is that you could copyright the play Romeo and Juliet (if you were Shakespeare and alive today), but not the idea of starcrossed lovers doomed because of blood enmity between their people. Thus, West Side Story would not have infringed on Romeo and Juliet, even though it exploited the same basic idea. By contrast, had the word "starcrossed" appeared in West Side Story, a tiny bit of Shakespeare's expression would have been copied - although not enough, by itself, to constitute infringement.

Distinguishing ideas from expression is notoriously tricky. If West Side Story seems to some a classic example of protected speech under the idea/expression distinction, ${ }^{60}$ it seems to the authors of the most influential copyright treatise an illustration of prohibitable copying. ${ }^{61}$ But put aside the elusiveness of the distinction. Assume arguendo that distinguishing ideas from expression is coherent in theory and workable in practice. It still cannot insulate copyright from the First Amendment.

Why is the idea/expression distinction thought to alleviate First Amendment problems? The implicit syllogism runs as follows. Laws that leave everyone free to communicate whatever ideas they like whenever and wherever they like raise no serious First Amendment concerns. Copyright leaves everyone free in just this way because copyright confers rights only in particular expressions, only in particular forms of words, and never in ideas themselves. Accordingly, copyright raises no serious First Amendment concerns. ${ }^{62}$

But the major premise is false. Outside copyright law, First Amendment jurisprudence systematically rejects the notion that a regulation of speech is constitutional if it "merely" prohibits particular forms of expressing ideas, rather than the ideas themselves. Take the famous case of Cohen v. California, which overturned the conviction of a man whose

59. Harper \& Row, 471 U.S. at 556 (paraphrasing approvingly N.Y. Times Co. v. United States, 403 U.S. 713, 726 n.* (1971) (Brennan, J., concurring)).

60. See, e.g., Nash v. CBS, 899 F.2d 1537, 1540 (7th Cir. 1990); Trotter Hardy, The Copyrightability of New Works of Authorship: "XML Schemas" as an Example, 38 HoUS. L. REV. 855,868 (2001).

61. 4 NIMMER, supra note 58, § 13.03[A][1][b], at 13-33 (arguing that West Side Story's "essential sequence of events, as well as the interplay of the charactcrs, [is] straight out of 'Romeo and Juliet"'). The treatise concedes that "not all courts would" agree. Id. at 13-34.

62. See, e.g., Melville B. Nimmer, Does Copyright Abridge the First Amendment Guarantees of Free Speech and Press?, 17 UCLA L. REV. 1 180, 1189 (1970) (contending that "the market place of ideas" essential to the maintenance of "the democratic dialogue" is protected so long as people can freely discuss "ideas"). 
jacket had the words "Fuck the Draft" on the back. ${ }^{63}$ In every case like Cohen, the idea/expression distinction is central. The state's position is that it would not dream of censoring ideas; it seeks to forbid "only form of expression"--only particular words, only a particular manner of expressing one's ideas. ${ }^{64}$

Cohen was free to express his ideas in a thousand different ways. California was-or at least could have plausibly claimed to be-fully prepared to protect anti-draft ideas, so long as the speaker did not engage in certain expressions of these ideas. If the First Amendment protected only ideas, and not particular expressions thereof, Cohen should have gone to jail.

The Court's flag-burning cases ${ }^{65}$ stand on the same principle. If the government were immune from First Amendment challenge whenever it banned only a particular expression of ideas, but not the ideas themselves, prohibiting flag "desecration" would be constitutionally unproblematic. The same logic, taken to its conclusion, would banish art altogether from constitutional protection. A state that banned poetry could say that it was prohibiting no ideas, but only particular forms of expression thereof. If the idea/expression distinction genuinely bought copyright a First Amendment immunity, the price might ironically be the stripping of First Amendment guarantees from much of the work, perhaps every work, to which copyright attaches. ${ }^{66}$

63. 403 U.S. 15 (1971).

64. As the Court put it, the question was whether Cohen's "conviction... can be justified ... as a valid regulation of the manner in which" he had expressed his idea. Id. at 19. Others have noted a connection between Cohen and the idea/expression distinction. See, e.g., Rebecca Tushnet, supra note 30, at 8-9.

65. See, e.g., Texas v. Johnson, 491 U.S. 397 (1989) (overturning a flag desecration conviction).

66. Because First Amendment law is generally more tolerant of "time, place, and manner" regulations, see, e.g., Thomas v. Chi. Park Dist., 122 S. Ct. 775, 779-80 (2002), one might wonder whether copyright's idea/cxpression distinction ought at least to qualify copyright law as a mere "manner" regulation (on the ground that it restricts only the "manner" in which a person expresses certain ideas). The claim would then be that copyright should be analyzed under the so-called time, place, and manner test, an intermediate level of First Amendment review more lenient than "strict scrutiny." See, e.g., Ward v. Rock Against Racism, 491 U.S. 781, 800 (1989). This way of thinking is problematic for at least two reasons. First, the more lenient time, place, and manner test applies only to content-neutral regulations, see, e.g., Thomas, $122 \mathrm{~S}$. Ct. at 779, and copyright law is almost certainly content-based in at least some of its applications, see supra note 18; infra Section IV.A. Second, the concept of "mere manner regulations" entitled to less stringent First Amendment review is much trickier than is usually recognized. In cases like Cohen or Texas $v$. Johnson, the laws struck down might equally have been called manner regulations. Every ban of offensive or symbolic speech can be said to restrict only a "manner" of speaking, but as Cohen and Johnson illustrate, such "manner regulations" can be clear First Amendment violations, not entitled to lenient review. In general, a law that, like copyright, makes people liable for speaking, see infra Subsection II.D.1, should never be viewed as a "mere manner" regulation. 
Government cannot evade the First Amendment by claiming to regulate "only the expression," not the idea. Through its protection of art, symbolic speech like flag burning, and offensive language, First Amendment law clearly and emphatically rejects this position. If copyright law is constitutional, the idea/expression distinction cannot explain why.

\section{Free Speech and Fair Use}

Fair use is the other piece of copyright law said to allay free speech concerns. ${ }^{67}$ In the Second Circuit's words: "We have repeatedly rejected First Amendment challenges to injunctions [against] copyright infringement on the ground that First Amendment concerns are protected by and coextensive with the fair use doctrine." 168

What is the fair use doctrine? It is a defense to copyright claims, originally developed by judges and later statutorily recognized, allowing infringement upon a finding that the defendant engaged in "fair use" of the copied material. ${ }^{69}$ By statute, judges are to consider four factors in determining whether a given use is "fair": (1) the "purpose and character of the use," (2) the "nature of the copyrighted work," (3) the "amount and substantiality" of the copying, and (4) "the effect of the use upon the potential market for or value of the copyrighted work." factor-supplanting the market for the copyrighted work, including the market for derivative works (such as movie versions or sequels) based on the copyrighted work ${ }^{71}$ - has been called the "most important." 72

Despite this enumeration of factors, the fair use doctrine is even more notoriously opaque than the idea/expression distinction. Commentators

67. See, e.g., Harper \& Row, Publishers, Inc. v. Nation Enters., 471 U.S. 539, 560 (1985); A\&M Records, Inc. v. Napster, Inc., 239 F.3d 1004, 1028 (9th Cir. 2001); Eldred v. Reno, 239 F.3d 372, 376 (D.C. Cir. 2001), cert. granted sub nom. Eldred v. Ashcroft, 122 S. Ct. 1062 (2002); L.A. News Serv. v. Tullo, 973 F.2d 791, 795-96 (9th Cir. 1992).

68. Nihon Keizai Shimbun, Inc. v. Comline Bus. Data, Inc., 166 F.3d 65, 74 (2d Cir. 1999).

69. For general discussions, see Harper \& Row, 471 U.S. at 560-69; Pierre N. Leval, Toward a Fair Use Standard, 103 HARV. L. REV. 1105 (1990).

70. 17 U.S.C. $\$ 107(2000)$.

71. Formerly a disputed point, it is now settled that market-substitution encompasses harm to the copyright holder's right to market derivative works. See, e.g., Campbell v. Acuff-Rose Music, Inc., 510 U.S. 569, 593-94 (1994); Castle Rock Entm't, Inc. v. Carol Publ'g Group, Inc., 150 F.3d 132, 145 (2d Cir. 1998); Toho Co. v. William Morrow \& Co., 33 F. Supp. 2d 1206, 1217 (C.D. Cal. 1998); Paramount Pictures Corp. v. Carol Publ'g Group, 11 F. Supp. 2d 329, 336 (S.D.N.Y. 1998).

72. E.g., Robinson v. Random House, Inc., 877 F. Supp. 830, 842 \& n.4, 843 (S.D.N.Y. 1995); 4 NIMMER, supra note $58, \S 13.05$ [Ä][4], at 13-182 ("If one looks to the fair use cases, if not always to their stated rationale, [the effect on the plaintiff's potential market] emerges as the most important, and indeed, central fair use factor." (footnotes omitted)); see also Campbell, 510 U.S. at 593-94 (emphasizing market-substitution factors and remanding for trial on this issue). 
routinely refer to this doctrine as "resistant to generalization," "73 "unpredictable,"74 and "subjective."75 But once again, let's assume away the uncertainties surrounding the doctrine's application. Assume, counterfactually, that knowledgeable people could determine in advance whether a given use was fair in every case. Even so, the fair use doctrine cannot explain copyright's First Amendment immunity.

In fact, the fair use doctrine arguably compounds copyright's First Amendment difficulties. Under the first factor of fair use doctrine (nature or purpose of the use), "parodic" and "critical" treatments of copyrighted material are highly favored. ${ }^{76}$ In other words, if you and I borrow exactly the same amount of material from a copyrighted work, I may escape liability because my speech criticized the copyrighted work, while you may be forced to pay damages because yours did not. ${ }^{77}$ Commentators typically present the "parody" and "criticism" features of fair use doctrine as a First Amendment plus or even a First Amendment "surrogate." ${ }^{78}$ They do not seem to notice that it renders copyright law viewpoint-discriminatory, which, as noted earlier, amounts almost everywhere else in free speech law to virtually a per se constitutional violation. ${ }^{79}$

73. Lloyd L. Weinreb, Fair's Fair: A Comment on the Fair Use Doctrine, 103 HARV. L. REV. 1137, 1138 (1990).

74. Naomi Abe Vocgtli, Rethinking Derivative Rights, 63 BROOK. L. REV. 1213, 1266 (1997) (referring to the fair use "doctrine, which many find unpredictable, if not incomprehensible").

75. Jessica Litman, The Public Domain, 39 EMORY L.J. 965, 1005 (1990). The vagueness of the fair use doctrine is itself a First Amendment problem. Even now, for example, it remains unsettled whether The Wind Done Gone was a fair use. The Eleventh Circuit, leaving the issue open for trial, noted that there was as yet no decisive evidence as to whether The Wind Done Gone would function as a "market substitute" for Gone with the Wind (or authorized sequels thereto), which might preclude a fair use finding. SunTrust Bank v. Houghton Mifflin Co., 268 F.3d 1257, 1274-77 (11th Cir. 2001). Although The Wind Done Gone was published notwithstanding, the vagueness of the fair use doctrine must surely have the proverbial "chilling effect" on some protected speech.

76. See 17 U.S.C. $\S 107$ (2000) (listing "criticism" and "comment" as examples of uses weighing in favor of fair use); Campbell, 510 U.S. at 578-85 (describing "parody" as a form of "critical" "commentary" favoring a fair use finding).

77. Compare Metro-Goldwyn-Mayer, Inc. v. Showcase Atlanta Coop. Prods., Inc., 479 F. Supp. 351, 362 (N.D. Ga. 1979) (enjoining Scarlett Fever, a musical comedy, as too imitative of plaintiff's film, Gone with the Wind, without being "critical" thereof), with SunTrust Bank, 268 F.3d at 1270-71 (finding The Wind Done Gone sufficiently critical of Gone with the Wind and vacating the injunction). See also Campbell, 510 U.S. at 578-79 (finding that 2 Live Crew's Pretty Woman parodied Roy Orbison's original song Oh Pretty Woman and therefore remanding the infringement finding).

78. The Supreme Court, 1993 Term-Leading Cases, 108 HARV. L. REv. 139, 337 (1994) ("For parodies in particular, the fair use doctrine must also play another critical role: an adequate surrogate for the First Amendment."); see, e.g., Denicola, supra note 58, at 293-99; Ruth Okediji, Givers, Takers, and Other Kinds of Users: A Fair Use Doctrine for Cyberspace, 53 FLA. L. REV. 107,130 (2001) (noting that in "fair use jurisprudence," "[u]ses, for purposes of criticism or review, are protected to reinforce First Amendment goals").

79. See supra text accompanying note 24; cf. Tushnet, supra note 30, at 25-27 (questioning whether fair use doctrine might raise constitutional difficulties because it is content-based). 
This argument may puzzle, however, because it asserts that what looks like a First Amendment good (the favoring of critical speech) can be a First Amendment evil. So put this point aside. There is another, simpler reason why fair use doctrine cannot substitute for First Amendment analysis. Fair speech is not free speech.

Copyright is not the only domain in which legislators have sought to make the legality of speech depend on criteria of "fairness"; it may, however, be the only body of law in which a fairness doctrine is viewed as a First Amendment surrogate, rather than a First Amendment problem. Once, in the well-known Red Lion case, the Supreme Court upheld a "fairness doctrine" that imposed evenhandedness and right-of-reply requirements on radio and television broadcasters. ${ }^{80}$ But Red Lion famously relied on facts specific to the broadcast industry circa 1969-especially spectrum scarcity ${ }^{81}$ and in subsequent cases, the Red Lion framework has not been followed. ${ }^{82}$ The Court has expressly struck down a "fairness doctrine" applied to newspapers ${ }^{83}$ and has repeatedly, if implicitly, affirmed the principle that speech need not be fair in order to be constitutionally protected. $^{84}$

First Amendment speech "is often not reasoned or evenhanded, but slashing and one-sided. ${ }^{85}$ As a result, free speech and fair speech are not interchangeable concepts. They are concepts at war. Free and fair elections may be a coherent aspiration. But free and fair speech are two very different things - at least when state actors are put in charge of determining what speech counts as fair.

It will be objected that I am playing on very different meanings of "fair." Yes, someone might say, laws that impose on speakers requirements of balance or reasonableness are almost always unconstitutional, but copyright's fair use doctrine is concerned with totally different factors, such as whether the speech at issue is offered for profit, whether it has borrowed more of the copyrighted work than was necessary, and perhaps most important, whether it will serve as a market substitute for the copyrighted

80. Red Lion Broad., Co. v. FCC, 395 U.S. 367 (1969).

81. Id. at 390-92.

82. See, e.g., Reno v. ACLU, 521 U.S. 844,870 (1997) (rejecting the Red Lion framework for Internet regulations); Turner Broad. Sys., Inc. v. FCC, 512 U.S. 622, 637-41 (1994) (rejecting the Red Lion framework for cable television regulations).

83. See Miami Herald Publ'g Co. v. Tornillo, 418 U.S. 241 (1974) (striking down a statute requiring newspapers to give equal reply space to criticized candidates).

84. See, e.g., Hustler Magazine, Inc. v. Falwell, 485 U.S. 46 (1988) (holding protected a cartoon suggesting that a well-known evangelist had sexual relations with his mother); Collin v. Smith, 578 F.2d 1197 (7th Cir.), stay denied, 436 U.S. 953 (1978) (upholding the right of a Nazi party to demonstrate in Skokie, Illinois, where, of some 70,000 residents, about 40,000 were Jewish and several thousand were Holocaust survivors and their families).

85. Hustler Magazine, 485 U.S. at 54. 
work. ${ }^{86}$ Hence, it might be said, the general unconstitutionality of "fairness doctrines," where unfair means one-sided or unreasonable, in no way casts doubt on copyright's fair use doctrine, where fairness refers to very different criteria.

This objection is peculiar. The kind of fairness requirements it concedes to be unconstitutional employ criteria (balance, rights of reply, reasonableness) especially sensitive to values typically touted as central to the First Amendment: enhancement of public discourse, encouragement of wide debate, the pursuit of truth or at least of reasoned conclusions, and so on. In other words, supporters of these fairness requirements can intelligibly claim that they do not violate the freedom of speech because they further, and are based solely on, the First Amendment's own core values. ${ }^{87}$ By contrast, copyright's fairness requirements are not nearly so sensitive to First Amendment concerns. Copyright's fair use exception is largely "econocentric",; it is organized to a considerable extent around the idea of faimess to the copyright owner's economic interests. How then can it be supposed that the unconstitutionality of fairness requirements outside of copyright law, which are ostentatiously public-discourse-sensitive, does not reflect badly on copyright's fairness requirements, which cannot even pretend to be based solely on the First Amendment's core values?

Imagine a statute prohibiting people from expressing their opinions about copyright law. Everyone understands that this statute would be unconstitutional. But wait: The statute has a proviso exempting "fair" expression. Is the law constitutional now? Perhaps it depends on how fairness is defined. Consider two possibilities.

In the first, fairness is defined according to criteria organized around the ideals of reasoned public discourse and democratic self-government. Thus, in determining whether a given expression of opinion was fair, judges or juries are to consider the merits of the opinion, the evenhandedness of the expression, its balance, its reasonedness and reasonableness, its openness to rival viewpoints, and so on. I take it that even with fairness so defined, the imaginary statute remains unconstitutional. At any rate, I take it that most American courts would strike it down without hesitation.

Now consider a quite different definition of fairness. In determining whether a given opinion about copyright law was fair, judges and juries are

86. See, e.g., Campbell v. Acuff-Rose Music, Inc., 510 U.S. 569, 584-94 (1994); supra note 72 and accompanying text.

87. See, e.g., Cass R. Sunsten, Democracy and the Problem of Free SPeech, at $x$ vixx, 113 (1993); Owen M. Fiss, Free Speech and Social Structure, 71 IOWA L. REV. 1405, 1415-16 (1986).

88. See David Lange \& Jennifer Lange Anderson, Copyright, Fair Use and Transformative Critical Appropriation, at http://www.law.duke.edu/pd/papers/langeand.pdf (last visited Sept. 16, 2002). 
to consider whether the opinion was expressed for commercial purposes; whether it referred to copyright law no more than was necessary; and most important, whether it advanced a rival intellectual property scheme that might serve as a substitute for copyright law in the market for legal goods. If the first definition of fairness was incapable of saving the statute, surely the same is true of the second.

To emphasize the economic focus of copyright's fair use doctrine is not to attack that doctrine. This economic orientation is perfectly logical given the economic goal (creating appropriate incentives to stimulate the production of valuable works) that copyright is usually supposed to serve. The point is simply that this economically oriented fair use doctrine cannot remotely be viewed as "coextensive" with First Amendment analysis. When the Eleventh Circuit remanded the Wind Done Gone litigation, the appellate court observed that the fair use defense could fail if, at trial, the plaintiff proved that sales of The Wind Done Gone operated as a market substitute for Gone with the Wind (or potential sequels thereto). ${ }^{89}$ This conclusion is perfectly justifiable if a use is to be deemed unfair in copyright cases when it captures profits that ought, either for reasons of efficiency or desert, to go to the copyright owners. But no one can suppose that this kind of faimess doctrine is congruent with, or could somehow exhaust or substitute for, free speech analysis.

Outside the domain of copyright, courts would quickly reject a governmental effort to force otherwise protected speech to pass a fairness test, no matter whether the fairness test at issue was sensitive to First Amendment values, and no matter whether the speech in question consisted of opinions about copyright law, art, pornography, or even jokes. Why, then, do so many people think of copyright's fair use defense as a First Amendment substitute? The reason, I suspect, is that they start with the presumption that copyrighted speech is somehow, at least in general, unprotected speech, so that the fair use defense comes in to rescue certain acts of infringement (news reporting, critical commentary, scholarship, and so on) that seem especially valuable from a First Amendment point of view. But copyrighted speech is not unprotected. It is undoubtedly protected when, for example, the copyright owner utters it. Indeed, the whole First Amendment question posed by copyright law is how government may constitutionally block some people, but not everyone, from engaging in certain otherwise protected speech acts. Even with respect to persons other than the copyright owner, no court has ever held that copyrighted speech is unprotected. On the contrary, courts hold "that First Amendment concerns

89. See SunTrust Bank v. Houghton Mifflin Co., 268 F.3d 1257, 1275.76 \& n.32 (11 th Cir. 2001). 
are protected by and coextensive with the fair use doctrine"; ${ }^{90}$ were copyrighted speech unprotected, there would be no First Amendment concerns for fair use doctrine to be "coextensive" with.

A fair use doctrine may be constitutionally necessary to copyright law, but it cannot be sufficient. If copyright law were subject to the ordinary First Amendment rules and principles that apply to protected speech, no fair use exception could save it. The problem lies, therefore, in saying why copyright is not governed by the First Amendment's ordinary rules and principles.

\section{Law and Economics}

The law-and-economics defense of copyright's constitutionality tries to solve this problem. Copyright does not violate the First Amendment, the economic argument goes, because (and to the extent that) it provides incentives that maximize overall production of valuable speech. Ex post, to be sure, any particular copyright can and will function as a limited monopoly, raising the costs of, and thereby suppressing, worthwhile speech. But these ex post restrictions are necessary to get the ex ante incentives right, and the result is an overall net First Amendment gain. ${ }^{91}$

It is uncertain whether copyright law in fact produces a net gain of this kind. A quite different view says of copyright law (as well as of the rest of current intellectual property law) that the monopolies it creates are inefficient, overprotective, and counterproductive to innovation. ${ }^{92}$ Indeed, some say that the success of the "copyleft" and "open source" movements in software development undermines the entire economic philosophy behind traditional intellectual property law. ${ }^{93}$ For present purposes.

90. Nihon Keizai Shimbun, Inc. v. Comline Bus. Data, Inc., 166 F.3d 65, 74 (2d Cir. 1999).

91. Without engaging in actual economic analysis, courts and commentators have frequently defended copyright in these or similar terms. See, e.g., Harper \& Row, Publishers, Inc. v. Nation Enters., 471 U.S. 539, 558 (1985) (referring to copyright's economic incentives as "the engine of free expression"); Mazer v. Stein, 347 U.S. 201, 219 (1954) ("The economic philosophy behind the clause empowering Congress to grant patents and copyrights is the conviction that encouragement of individual effort by personal gain is the best way to advance public welfare."); Tushnet, supra note 30, at 35-37 (justifying copyright's constitutionality on this ground). See generally Mark A. Lemley, Romantic Authorship and the Rhetoric of Property, 75 TEX. L. REV. 873, 879-95 (1997) (reviewing JAMES BOYLE, SHAMANS, SOFTWARE, AND SPLEENS: LAW AND THE CONSTRUCTION OF THE INFORMATION SOCIETY (1996) and collecting authorities).

92. See, e.g., Benkler, supra note 30, at 377-84; James Boyle, Cruel, Mean or Lavish? Economic Analysis, Price Discrimination and Digital Intellectual Property, 53 VAND. L. REV. 2007, 2010-11 (2000); Michael A. Heller \& Rebecca S. Eisenberg, Can Patents Deter Innovation? The Anticommons in Biomedical Research, 280 SCIENCE 698 (1998). Particularly forceful economic arguments have been made against copyright owners' exclusive right to produce "derivative works." See infra note 165.

93. See, e.g., GLYN MOODY, REBEL CODE: THE INSIDE STORY OF LINUX AND THE OPEN SOURCE REVOlUTION (2001); Eben Moglen, Anarchism Triumphant: Free Software and the 
however, I will assume that copyright law in general causes more rather than less speech to be produced overall. The question is whether this fact justifies copyright under the First Amendment.

One of the chief appeals of the law-and-economics approach is that it weaves together the policy analysis of copyright law-the analysis of how well a given copyright regime furthers the goal of promoting the production of valuable works-with the First Amendment analysis. If copyright law gets the economics right, speech will be maximally incentivized, and copyright will therefore be constitutionally unobjectionable. From this point of view, the policy analysis is the First Amendment analysis.

But this conflation of policy analysis and First Amendment analysis ought to sound an alarm bell. The ideal image conjured up here is of a First Amendment jurisprudence in which the validity of copyright statutes would depend on the resolution of incredibly complex empirical questions of economic efficiency. The problem with this image is not merely that judges are asked to do something they are incompetent to do. The problem is that the ideal of free speech implicit in this image is the wrong one.

Again consider Cohen v. California, the "Fuck the Draft" case. Suppose California's lawyers had read the recent law-and-economics copyright literature. They realize that they have overlooked all along the true reason why their statute is constitutional. Prohibiting bad, uncivil words, they now say, produces more speech for society overall. Offensive words, they say, cause many people to retreat from public dialogue.

This is an empirical claim, and-who knows?-it may be true. It is the same kind of claim that is sometimes made about "hate speech" and pornography. Such speech, this argument goes, has a "silencing" effect. On this view, prohibitions of hate speech and pornography should "be seen as efforts not to suppress speech, but to maximize it."94

Perhaps offensive speech and copyright infringement really do have a "silencing" effect, ultimately producing less speech overall. Come to think of it, perhaps a knockdown argument is also silencing. Earlier I said that a person could not be jailed for the crime of "unfairly" criticizing copyright law. Are we to understand that a person can be jailed for making too good

Death of Copyright, 4 FIRST MONDAY 1 (Aug. 2, 1999), at http://firstmonday.org/ issues/issue4_8/moglen/index.html. The "copyleft" or "open source" license permits code to be "freely copied, modified, and distributed, but only if the modifications (derivative works) are distributed on these terms as well." David McGowan, Legal Implications of Open-Source Software, 2001 U. ILL. L. REV. 241, 242. The license in effect deploys copyrights to eliminate copyrights.

94. Mark Tushnet, Thinking About the Constitution at the Cusp, 34 AKRON L. REV. 21, 30 (2000); see also CATHARINE A. MACKINNON, ONLY WORDS 9 (1993) ("[P]omography and its protection have deprived women of speech, especially speech against sexual abuse."); Charles $\mathbf{R}$. Lawrence III, If He Hollers Let Him Go: Regulating Racist Speech on Campus, 1990 DUKE L.J. 431,471 ("[R]acist speech decreases the total amount of speech that reaches the market."). 
an argument against copyright law, an argument so good it brings debate to an end, leaving its audience with little or nothing to say?

The reply from those who make economic arguments for speech suppression (whether the speech to be suppressed consists of copyright infringement, hate speech, or something else) might be to distinguish between "bad" silencing speech, which impedes nice, diverse, truth-seeking public discussion, and "good" silencing speech, like a conclusive argument, which may also bring discussion to an end, but only for appealing, truthseeking, publicly endorsable reasons. This distinction makes the economist's argument worse, not better. Before, the economist appealed solely to the idea of speech "maximization"; speech acts were to be suppressed on the ground that allowing them would produce less speech overall, not on the ground of any overt value judgments disfavoring them. When, however, the law-and-economist begins distinguishing between "good" and "bad" silencing speech, then judges or legislators are asked to pass judgments that the First Amendment does not allow. Plato thought that poetry had a poisonous, soporific effect on truth-seeking dialogue. ${ }^{95}$ Say that a judge or legislature credited that empirical claim; say even that the claim were true. It would not follow that poetry could be banned. First Amendment rights do not work that way.

If speech could be suppressed whenever suppression produced on the whole a net gain in valuable public discussion, we would live in a First Amendment world very different from the one we have known. The truth is that banning a book can often be expected to provoke much more good public discussion about the topics it raises than the book's unfettered publication would have generated. Again, The Wind Done Gone provides an example. It would be a strange First Amendment-it would not be the American First Amendment-that asked judges to calculate the speech produced by banning books, subtract the speech that would be yielded by the book's publication, and if the remainder is positive, uphold censorship as an engine of free expression.

Which is simply to say: The First Amendment's objective is not maximization of total speech production. And it is certainly not the achievement of an efficient speech market, generating exactly as much speech as people are willing to pay for. The policy objective of copyrightthe establishment of ex ante incentives maximally stimulating production of profitable work-is not the First Amendment's objective. Just as free speech cannot be reduced to fair speech, neither can it be reduced to

95. See Plato, ThE RePUBlic, bk. X, at 313-45 (G.R.F. Ferrari ed. \& Tom Griffith trans., Cambridge Univ. Press 2000). 
efficient or wealth-maximizing speech. The Constitution cannot be economized.

\section{The Property Intuition}

So much for the most prominent arguments purportedly explaining copyright's First Amendment immunity. For many, however, copyright's constitutionality rests less on argument than on a powerful intuition: Copyrighted works are private property. If you wrote Gone with the Wind, Rhett and Scarlett belong to you. Of course copyright law does not violate the freedom of speech; there is no First Amendment right to steal.

The property intuition seems to presuppose that authors have a kind of natural property claim to their original writings. ${ }^{96}$ By contrast, the official account of copyright law is that copyright is a solely statutory creation (there are no "common law copyrights" after publication), the primary purpose of which is "not to reward the labor of authors, but " $[t]$ o promote the Progress of Science and useful Arts.",97

Nevertheless, without the natural law gloss, American courts frequently express something like the property intuition in defending copyright from First Amendment challenge. An often-quoted formulation from the Fifth Circuit is illustrative: "[T] he first amendment is not a license to trammel on legally recognized rights in intellectual property." 98 The phrase "trammel on" is slightly mysterious, since "on" is not used with "trammel," and since trammel means catch (as in a net) or confine. "Trample" may have been intended; at any rate its grammar may have slipped into the sentence. But the court's thought seems clear enough: One who trespasses on another's property cannot hide behind the First Amendment.

96. For accounts of copyright that emphasize this idea, see, for example, Wendy J. Gordon, An Inquiry into the Merits of Copyright: The Challenges of Consistency, Consent, and Encouragement Theory, 41 STAN. L. REV. 1343, 1469 (1989) (advocating a copyright jurisprudence "based on the notion that creative persons deserve a fair return for their labor"); and Alfred C. Yen, Restoring the Natural Law: Copyright as Labor and Possession, 51 OHIO ST. L.J. 517 (1990).

97. Feist Publ'ns, Inc. v. Rural Tel. Serv. Co., 499 U.S. 340, 349 (1990) (quoting U.S. CONST. art. I, § 8, cl. 8); see also Campbell v. Acuff-Rose Music, Inc., 510 U.S. 569, 578 n. 10 (1994); United States v. Paramount Pictures, Inc., 334 U.S. 131, 158 (1948) ("The copyright law, like the patent statutes, makes reward to the owner a secondary consideration."). United States law recognized a form of "common law copyright," but only until publication of the work. See, e.g., Wheaton v. Peters, 33 U.S. (8 Pet.) 591, 597-98 (1834); Batjac Prods., Inc. v. GoodTimes Home Video Corp., 160 F.3d 1223, 1225-26 (9th Cir. 1998).

98. Dallas Cowboys Cheerleaders, Inc. v. Scoreboard Posters, Inc., 600 F.2d 1184, 1188 (5th Cir. 1979), quoted in, e.g., Cable/Home Communication Corp. v. Network Prods., Inc., 902 F.2d 829, 849 (11th Cir. 1990); cf. Rochelle Cooper Dreyfuss, Expressive Genericity: Trademarks as Language in the Pepsi Generation, 65 NOTRE DAME L. REV. 397, 404-07 (1990) (observing the force of a similar property intuition in trademark law and showing how it has been used to weaken First Amendment protections). 
And as a general rule, this proposition is true. There is no First Amendment right to trespass. Say I am ejected from a theater for sneaking in without a ticket. Perhaps I am prosecuted. It will not do me much good to say that I have a First Amendment right to see any play I choose. "The First Amendment," the judge would presumably observe, "is not a license to tram[ple] on legally recognized rights in [private] property."

Ordinary property laws are fully enforceable, without any First Amendment review, even when they stop trespassers from engaging in First Amendment activity such as seeing a play. And isn't copyright a form of property law? Why shouldn't copyright law, therefore, be fully enforceable, without any First Amendment review, even when it stops infringers (trespassers) from engaging in First Amendment activity such as putting on a play? That is the question posed by the property intuition.

The answer is: because copyright creates property rights in speech, rather than merely in things.

Laws that turn speech into property differ from ordinary property laws in two critical respects. First, they make people liable for speaking, whereas ordinary property law does not. Second, they create a kind of private power over public speech that ordinary property law does not. For both these reasons, copyright raises fundamental First Amendment problems not presented by ordinary property law.

\section{Liability for Speaking}

Ordinary property law prevents you from laying hands on a thing without permission. Copyright law prevents you from speaking without permission. (I mean "speaking" here in the First Amendment sense, so that an act of speech can include not only uttering words, but also publishing a book, performing a piece of music, and so on.) Copyright law makes people liable for speaking. Ordinary property law does not.

This point may strike some readers as unclear or unfamiliar. An objection might run as follows: But ordinary property law can render people liable for speaking. Suppose protesters plant signs in the yard of a doctor who performs abortions. These people are liable in trespass, but surely they are "speaking" in the First Amendment sense.

Yes, but the ordinary property law that makes them liable in trespass does not make their speaking an element of the offense. The protesters commit trespass regardless of whether they were speaking through their conduct. In other words, while a given act of trespass can be highly expressive, trespass laws do not make this communicativeness any part of the offense of trespass. They do not condition liability on anyone's having engaged in a speech act. As a result, while trespass law may well prevent 
people from engaging in a particular speech act-planting signs on someone's land-it does not render them liable for speaking, in the sense of making their actions illegal because they were speaking.

Copyright law, however, does render people liable because they are speaking-and indeed, because of what they say. It makes their speech itself an element of the offense of infringement. This distinction is of clear and central importance to First Amendment law. ${ }^{99}$ It is the difference between arson and flag burning.

Imagine a person deliberately burning down a building by setting fire to an American flag. He is fully liable under ordinary tort and arson laws. Because these laws in no way concern themselves with the communicativeness of the defendant's conduct, he will have no First Amendment defense even if he was communicating a political opinion through his actions. There is no First Amendment privilege to commit arson.

But suppose this same person is charged, not under ordinary arson law, but under a law that prohibits "defacing or destroying an American flag in a fashion that intentionally communicates disrespect." Now the defendant will have a good First Amendment defense: The law is unconstitutional. ${ }^{100}$ And he will have a good defense even though he was free to express his ideas in countless other ways. The flag-burning law is unconstitutional precisely because it makes the communicativeness of the defendant's actions an element of the offense. ${ }^{101}$ It punishes him for speaking, whereas ordinary tort and arson laws punish him solely for his conduct. ${ }^{102}$

Rendering people liable for speaking does not make a law unconstitutional per se. Libel law conditions liability on speaking. Yet precisely because libel-like copyright, but unlike, say, the tort of batterymakes speech as such illegal, courts were eventually obliged to address and to redress its First Amendment consequences. ${ }^{103}$ Copyright stands to

99. For a general discussion of this point, see Jed Rubenfeld, The First Amendment's Purpose, 53 STAN. L. REV. 767, 776-84 (2001).

100. See R.A.V. v. City of St. Paul, 505 U.S. 377, 385 (1992). The Court stated:

[N]onverbal expressive activity can be banned because of the action it entails, but not because of the ideas it expresses - so that burning a flag in violation of an ordinance against outdoor fires could be punishable, whereas burning a flag in violation of an Id. ordinance against dishonoring the flag is not.

101. See Texas v. Johnson, 491 U.S. 397, 411-12 (1989) (reversing a conviction for flag desecration where the defendant's liability "depended on the likely communicative impact" of his conduct).

102. See Rubenfeld, supra note 99, at 776-77; infra Subsection III.C.2.

103. The watershed case was New York Times Co. v. Sullivan, 376 U.S. 254 (1964), in which the Court ruled that a public official libel plaintiff must prove "actual malice," a term of art meaning a knowing or reckless misrepresentation, id. at 280 . Even with respect to "private figures," the Court later held, states may not impose "liability without fault," nor authorize 
property law as libel stands to tort law; copyright makes speech property, as libel makes speech a tort. The difference is that copyright law remains in a pre-Sullivan condition. ${ }^{104}$ Its First Amendment problems are still masked by the property intuition- "there is no right to steal"- just as libel's First Amendment problems used to be masked by the assertion that there was no constitutional right to "destroy" business or personal reputation. ${ }^{105}$

The point, then, is not that copyright is automatically unconstitutional because it makes people liable for speaking. The point is only to reject a certain unthinking defense of copyright's constitutionality. The unthinking defense runs as follows. Major premise: There is no First Amendment right to trample on other people's property. Minor premise: Copyright is property. Conclusion: A copyright infringer can have no First Amendment defense.

This syllogism works well enough for ordinary property law, but not for copyright law. Copyright cannot claim ordinary property law's immunity from First Amendment scrutiny, because the reason that ordinary property law is immune from First Amendment attention does not apply to copyright. Ordinary property law raises no First Amendment problem because it does not render people liable for speaking. Copyright does.

\section{Private Power over Public Speech}

All property law creates private power over speech. Even a homeowner can exercise some power over others' speech-for example, by ejecting from his property people who criticize the President. But the kind of private power that copyright creates over speech is fundamentally different.

Why is the First Amendment untroubled when a homeowner engages in viewpoint discrimination on his premises? The doctrinal answer is that the First Amendment applies only to state action. But a stranger to our legal system might find this answer puzzling. If Americans consider viewpoint discrimination so intolerable that a constitutional proscription is called for, why should homeowners, exercising property rights secured by state law, be permitted to engage in it? Why, in other words, don't we consider the state action doctrine, insofar as it fails to cover content- or viewpointdiscriminating property owners, a gross compromise of First Amendment principles?

punitive damages in the absence of "actual malice." Gertz v. Robert Welch, Inc., 418 U.S. 323, 323-24 (1974).

104. For an incisive discussion using Sullivan as an analogy and point of departure for the constitutional analysis of copyright, see Boyle, supra note 30, at 340-48.

105. See, e.g., KVOS, Inc. v. Associated Press, 13 F. Supp. 910,912 (N.D. Wash. 1936). 
One important reason is that the private power over speech conveyed by ordinary property law is subject to an important inherent restriction. It is limited to speech that takes place on or with the use of the owner's property. To be sure, even with this limitation, property ownership can for some owners-for example, the owners of the New York Times-generate considerable power over others' speech. But no owner, under ordinary property law, has a general power simply to block the public at large from engaging in expression that the property owner has not authorized. A homeowner may not invite you to dinner if you use words he doesn't like, and a newspaper may refuse to print your stories, but you remain legally free to utter those words or tell those stories in public, to post them on the Internet, to publish a book containing them (if you can find a publisher), and so on. ${ }^{106}$

A second reason we accept the kind of private power over speech created by ordinary property law is that we tend to see property owners, when they invoke this power, as exercising First Amendment rights of their own. In the American understanding, people frequently have a constitutional right to use their private property for First Amendment purposes: to express their views, to hold meetings for like-minded people, to print books and newspapers, to make or display films, and so on. Turning all private property - homes, private schools, newspapers, movie theatersinto viewpoint-neutral free speech zones would be the realization, from this perspective, not of a First Amendment dream, but of a First Amendment nightmare. $^{107}$

Thus, while ordinary property vests in owners a certain power over others' speech, there are two substantial reasons we do not generally regard this power as inimical to the First Amendment. First, ordinary property owners have no power to shut down expression by the public at large. Second, individuals usually have a First Amendment right to use their property for the speech activities they prefer and to exclude unwanted

106. This is why a constitutional threshold is crossed when ordinary property owners seek to turn their power over property into a power to exclude speech from public access altogether. See Marsh v. Alabama, 326 U.S. 501, 501 (1946) (invalidating under the First Amendment a trespass prosecution of an individual who tried to distribute religious literature after having been told to leave by the corporate managers of a "company-owned town"); cf. Lloyd Corp. v. Tanner, 407 U.S. 551 (1972) (rejecting a First Amendment challenge to a shopping center's refusal to allow handbilling where individuals were free to handbill on the surrounding sidewalks).

107. Again, this point is borne out by "fairness doctrine" cases. See, e.g., Miami Herald Publ'g Co. v. Tornillo, 418 U.S. 241 (1974) (striking down a statute requiring newspapers to give equal reply space to criticized candidates); see also Pac. Gas \& Elec. Co. v. Pub. Util. Comm'n, 475 U.S. 1 (1986) (striking down a requirement that an electric company include in its billing envelopes speech by an advocacy group that had frequently opposed company's policies). But $c f$. Pruneyard Shopping Ctr. v. Robins, 447 U.S. 74 (1980) (upholding a state law forbidding a shopping center from excluding individuals seeking signatures for a political petition). 
speech from their property. Both these reasons disappear when we turn to copyright.

A copyright owner's power over speech applies to the public at large, anywhere and everywhere. While a homeowner may block certain texts from being recited on his premises, a copyright owner can block certain texts from being published, copied, or recited by virtually anyone, in public and often in private. This is the necessary result of creating property rights in speech itself. Copyright gives private parties legal control over everyone else's use of certain linguistic and expressive materials, including not only speech that directly copies those materials, but speech that is "based upon" ${ }^{108}$ them as well.

Second, when copyright owners exercise their statutory rights, they are not exercising First Amendment rights. The holder of J.K. Rowling's copyrights enjoys undoubted First Amendment protection in the sense that no governmental actor in the United States can ban the Harry Potter books (although some are apparently trying ${ }^{109}$ ). But when it comes to preventing others from copying these books, filming them, or writing sequels to them, the copyright holder has only statutory rights, not First Amendment rights. No one has a First Amendment right to be the only speaker of certain words. Authors have an undoubted First Amendment right to stop state actors from trying to control what they say, but they have no First Amendment right to block private actors from repeating what they say or from making use of what they say in derivative works.

Added together, these features of copyright law-that it creates liability for speaking, that it vests private parties with a power to block everyone else from engaging in certain expression, and that this power extends far beyond what the copyright owner could claim as a constitutional rightexplain why copyright cannot possess a First Amendment immunity in the same way that ordinary property law can. The fact that copyright makes speech itself into private property is not a vindication of copyright's constitutionality, but rather the cause of constitutional concern.

The property intuition says that copyright claims are immune from First Amendment scrutiny because there is no First Amendment right to trespass on someone else's "legally recognized intellectual property." The proposition proves far too much. If Congress could act with First Amendment impunity whenever it turned speech into property, the freedom of speech would turn out to mean a freedom to speak only at the sufferance of federally designated individuals or corporations. If there is no First

108. 17 U.S.C. $\S 106(2)(2000)$ (granting copyright owners the exclusive right to "prepare derivative works based upon the copyrighted work").

109. See Rob Boston, Witch Hunt: Why the Religious Right Is Crusading To Exorcise Harry Potter Books from Public Schools and Libraries, CHURCH \& ST., Mar. 1, 2002, at 8. 
Amendment right to "trammel on legally recognized intellectual property rights," then there would be no First Amendment problem with, say, a statute granting Microsoft the exclusive right to use English on the Internet.

Copyright cannot be constitutionally justified by analogy to ordinary property law, any more than copyright's constitutionality can be explained by the idea-expression distinction, the fairness doctrine, or the goal of maximizing cost-effective speech. To get a better answer-to understand both copyright's constitutionality and its unconstitutionality-we need a new framework for measuring copyright against the demands of free speech.

\section{THE FREEDOM OF IMAGINATION}

\section{A. Giant-Sized First Amendment Theories}

Giant-sized First Amendment theories tend to start with one or both of two giant-sized ideas: either democracy or individual autonomy. ${ }^{110}$ So understood, the initial task of First Amendment interpretation is to establish a theory of democracy or individual freedom. Once that hurdle is overcome, the interpreter need only derive from his theory of democracy or individual autonomy the requirements of free speech entailed thereby.

I will avoid this kind of approach. My starting point will be much narrower by comparison. The reason is principally methodological. Democracy- or autonomy-based theories of free speech essentially attempt to derive constitutional law from philosophy, and the First Amendment does not derive from philosophy. It does not "derive" at all. The First Amendment is not a "universal right of man"; it is a piece of the ineluctably political, historical United States Constitution.

Philosophical approaches to the First Amendment adopt a universalistic approach; the result, ironically, is parochialism. When people derive First

110. For autonomy-based accounts, see C. EDWIN BAKER, HUMAN LIBERTY AND FREEDOM OF SPEECH (1989); Thomas I. Emerson, Toward a General Theory of the First Amendment, 72 YALE L.J. 877, 879 (1963) ("The right to freedom of expression is justified first of all as the right of an individual purely in his capacity as an individual. It derives from the widely accepted premise of Western thought that the proper end of man is the realization of his character and potentialities as a human being."); and Thomas Scanlon, A Theory of Freedom of Expression, 1 PHIL. \& PUB. AFF. 204 (1972). The democracy-based defense of free speech is famously associated with AleXANDer MeIKLejoHn, Free SPEech and Its Relatton to SelfGOVERNMENT (1948). For other important work of this kind, see OWEN M. FISS, LIBERALISM Divided: FREedom of SPEECH AND THE MANY USES OF STATE POWER (1996); and SUNSTEIN, supra note 87. Of course, there are many who claim to embrace both the democracy-based and autonomy-based approaches to the First Amendment. See, e.g., ZECHARIA CHAFEE, FREE SPEECH IN THE UNITED States 33-35 (1967); ROBERT C. POST, CONSTITUTIONAL DOMAINS: DEMOCRACY, COMMUNITY, MANAGEMENT 276-78 (1995). 
Amendment rights from a theory of democracy or individuality, they imply that our freedom of speech - the one guaranteed by the United States Constitution-is in principle applicable to every democratic society or to every society that values individual autonomy. But America's freedom of speech reflects America's distinctive constitutional commitments, which other nations need not and do not share.

England has an established church. Germany forbids Nazi speech. ${ }^{111}$ Internationally, it is commonplace for scholars to observe that America's free speech law differs from, and is significantly stronger than, that of many other democratic, human-rights-respecting nations. ${ }^{12}$ America's First Amendment commitments are not, and should not be thought of as, universal requirements of democracy or individuality.

If prohibiting a national church or forbidding censorship of pro-Nazi speech were holdings marginal to American First Amendment law, the democracy- and autonomy-based approaches might more easily brush aside the fact that these holdings represent distinctively American commitments, rather than entailments of democracy or individual self-realization. But these holdings are not peripheral. They are central to the American First Amendment, definitive of its core meaning.

Because they are definitive in this way, such paradigmatic understandings of what the First Amendment prohibits offer a superior starting point for free speech jurisprudence. I begin with another paradigm case in what follows: the understanding that works of art are "unquestionably shielded" by the First Amendment. ${ }^{113}$

111. See Eric Stein, History Against Free Speech: The New German Law Against the "Auschwitz"-and Other-"Lies," 85 MICH. L. REV. 277, 323 (1986) (quoting the West German Criminal Code, arts. 130, 131, 185, 194 StGB).

112. See, e.g., Adrienne Stone, The Limits of Constitutional Text and Structure: Standards of Review and the Freedom of Political Communication, 23 MELB. U. L. REV. 668, 697-98 (1999). In fact, one quite plausible view maintains that on free speech issues "the law of the United States is precisely contrary to international human rights norms." David M. Smolin, Exporting the First Amendment?: Evangelism, Proselytism, and the International Religious Freedom Act, 31 CUMB. L. REv. 685, 694 (2000); see also International Covenant on Civil and Political Rights, adopted Dec. 19, 1966, art. 20(2), S. EXEC. Doc. E, 95-2, at 23 (1978), 999 U.N.T.S. 171, 178 (entered into force Mar. 23, 1976) ("Any advocacy of national, racial or religious hatred that constitutes incitement to discrimination, hostility or violence shall be prohibited by law."); Otto-Preminger-Institut v. Austria, 19 Eur. Ct. H.R. 34, 56, 60 (1994) (upholding censorship of a film under Austria's law protecting injury to religious feelings and suggesting that such censorship might be required by religious liberty and "the spirit of tolerance" that is "a feature of democratic society"). For a review of international human rights norms pertaining to hate speech, see Stephanie Farrior, Molding the Matrix: The Historical and Theoretical Foundations of International Law Concerning Hate Speech, 14 BeRKELEY J. INT'L L. 1 (1996).

113. Hurley v. Irish-Am. Gay, Lesbian \& Bisexual Group of Boston, 515 U.S. 557, 569 (1995). 


\section{B. The First Amendment Status of Art}

\section{Art's Protection}

"[W]holly neutral futilities," the Supreme Court said three decades ago, "come under the protection of free speech as fully as do Keats' poems or Donne's sermons." "114 This formulation is worth considering. It is important both for what it takes to be a paradigmatic bit of protected speech ("Keats' poems") and for what else it says the First Amendment protects ("wholly neutral futilities").

It hardly goes without saying that the freedom of speech should "fully" protect Keats. Any number of accounts of the First Amendment could be articulated that make early-nineteenth-century Romantic poetry of peripheral concern to the Constitution, or of no concern at all. ${ }^{115}$ If it is unquestionable that the First Amendment shields art-particularly nonverbal art, such as music or painting - it is certainly not because of the First Amendment's text, nor because of a philosophical necessity. Yet there it is: The "painting of Jackson Pollock, music of Arnold Schoenberg, or Jabberwocky verse of Lewis Carroll," the Court observed in 1995, is today "unquestionably shielded." 116

Why? No good answer will be found in the case law. On the contrary, the protection of a great deal of painting, music, dance, and sculpture is contraindicated by the well-established Spence test, under which nonverbal expressive activity is deemed protected only if "[a]n intent to convey a particularized message was present," and "the likelihood was great that the message would be understood by those who viewed it."117

The two best-known academic explanations of art's First Amendment status try, predictably, to force fit art into the two molds most favored by free speech theorists: democracy and individual autonomy. I have already suggested methodological reasons for skepticism about democracy- and

114. Cohen v. California, 403 U.S. 15, 25 (1971) (quoting Winters v. New York, 333 U.S. 507, 528 (1948) (Frankfurter, J., dissenting)).

115. For example, if the First Amendment is said to exist solely or primarily to protect "political speech," then bygone Romantic poetry is unlikely to excite much constitutional attention. See, e.g., SUNSTEIN, supra note 87, at 153-62 (arguing that nonpolitical art should receive lower-tier First Amendment protection); Robert H. Bork, Neutral Principles and Some First Amendment Problems, 47 IND. L.J. 1, 26-28 (1971) (arguing that art, insofar as it is not "political speech," should receive no protection).

116. Hurley, 515 U.S. at 569.

117. E.g., Texas v. Johnson, 491 U.S. 397, 404 (1989) (quoting Spence v. Washington, 418 U.S. 405, 410-11 (1974)). In Hurley, the Court expressly recognized that the Spence test would deny protection to a good deal of art "unquestionably shielded" by the First Amendment, yet did not explain whether, as a result, the cases relying on Spence are no longer good law, or whether works of art are "unquestionably shielded" because of some special characteristics that make Spence inapplicable. Hurley, 515 U.S at 569. 
autonomy-based approaches to the First Amendment. On the merits, as applied to art, they yield very partial, unsatisfactory understandings.

\section{Art, Democracy, and Expressive Autonomy}

Alexander Meiklejohn, one of the strongest proponents of the democratic-process view of the First Amendment, tried to explain art's constitutional protection through an expansive view of the material from which voters draw their opinions. ${ }^{18}$ "Literature and the arts," wrote Meiklejohn, are among the "many forms of thought and expression... from which the voter derives the knowledge, intelligence, [and] sensitivity to human values" exercised when casting a ballot. ${ }^{119}$ Hence in a democracy, art must be constitutionally protected.

Few have found this "art in the ballot booth" argument satisfying. ${ }^{120}$ It puffs art up, but for the wrong reasons, and thereby demeans it at the same time. Suppose someone said that prayer contributes to the formation of political opinion. This statement might not exactly be false, but it would be highly unattractive if offered in explanation of prayer's constitutional protection. It would exaggerate prayer's political significance while instrumentalizing it, making it carry democracy's water. The same holds for the democratic-process view of art's protection. ${ }^{121}$

If beauty were truth, and truth the end of democratic politics, then art might be politics, and politics art. The truth, however, is that art may well be undemocratic-and radically so. In any event, the infinitesimal influence that Schoenberg's music might conceivably have on the casting of ballots makes no sense of its "unquestionable" constitutional protection.

The other familiar explanation of art's First Amendment status is that art is a sublime expression of individual autonomy-or expressive autonomy, as it is sometimes called. ${ }^{122}$ On this view, art is protected because it is the apogee of self-expression and self-determination.

118. Alexander Meiklejohn, The First Amendment Is an Absolute, 1961 SUP. CT. REV. 245, 255-57.

119. Id. at 256-57.

120. Supporters of art's protection find it too cramped, see, e.g., Martin H. Redish, The Value of Free Speech, 130 U. PA. L. REV. 591, 601, 604 (1982), while supporters of the democraticprocess account of free speech deem it too expansive, see, e.g., Bork, supra note 115, at 26-28.

121. In this respect, the democratic-process view of art in First Amendment law is an instance of what De Duve calls one of "the most important, and the most tragic mistakes . . of modernity, namely, the mapping of the aesthetic field onto that of political economy." THIERRY DE DUVE, KANT AFTER DUCHAMP 450 n.16 (1996).

122. See, e.g., BAKER, supra note 110 , at $47-51$ 
Expressing oneself in "writing, pictures and music" can be central to "a mature person's" "autonomous self-determination.", 23

The self-expression view of art tells us that art serves one of modernity's master ideas (individual autonomy), just as the democraticprocess view makes art serve another (democracy). If the latter makes art too political, the former makes it too narcissistic. To say that art is "selfexpression" or "self-realization" is about the most self-centered way of describing what artists do (even if many artists seem determined to bear it out), and it renders, from a First Amendment point of view, altogether too peripheral or secondary what audiences do.

Am I "expressing myself" or "realizing myself" when I read Keats's poems? If art is an artist's "self-expression," then the audience is essentially a consumer, a voyeur, or, at best, an interpreter of another's act of selfexpression. Some readers of Keats may so thrill to his words that they feel they are "expressing themselves" each time they read him. But surely for many readers, nothing like this is true. If I am not myself engaged in selfexpression or "self-realization" when I read Keats, and if self-expression or self-realization is the key to First Amendment protection, does it follow that my activity is subject to state regulation or even prohibition?

A proponent of the self-expression view will of course say no. He will say, perhaps, that the artist's right to self-expression includes the right to have his work put before the public. Expression requires an expressee as well as an expresser, so the artist's right of self-expression would not be protected if the state could ban the reading or viewing of his work.

This picture is unsatisfactory. The self-expression view of art comes to audience rights as a derivative thing, a kind of logical necessity implied secondarily if we are going to give artists the freedom to which they are entitled. But the reading of a book is not, for First Amendment purposes, to be regarded as a mere instrument of that which is "really" protected, the writer's self-expression.

A law that jailed you for reading Keats would not violate the First Amendment because it impeded Keats's rights of self-determination. Keats has no rights; he is dead. Nor would the law be unconstitutional because it violated the rights of publishers. The law would violate your constitutional rights - directly, without need of reference to anyone else's rights.

I am not calling for a theory of art in which the reader's role in "making" the work is seen as equivalent or superior to the writer's. I am not calling for a theory of art at all; the First Amendment does not need a theory of art. The constitutional question is not what art is, but what the

123. David A.J. Richards, Free Speech and Obscenity Law: Toward a Moral Theory of the First Amendment, 123 U. PA. L. REV. 45, 62 (1974). 
First Amendment prohibits. And one of the things the First Amendment centrally prohibits is a law that criminalizes the reading of books, including dead writers' books, and including the reading of books by persons for whom such reading is not an act of self-expression or self-realization. The expressive autonomy position does not do a very good job of telling us why the reading of a book should be paradigmatically - not secondarilyconstitutionally protected.

By contrast, the democracy-based account of the First Amendment can robustly capture the direct constitutional protection of reading (rather than merely writing) books. Unfortunately, it cannot apply to art without falsely politicizing it. This one-sidedness on both sides of the aisle is characteristic of the entire debate between democracy-based and autonomy-based accounts of the First Amendment.

\section{Greatness and Futility}

To get beyond this debate, it is necessary to see that both these approaches try to explain the constitutional protection of art in terms of art's special value - either to the democratic process (and hence to the flourishing of the polity) or to individual self-realization (and hence to the flourishing of the individual). From this point of view, it is not coincidental that the Court made reference (in the formulations quoted earlier) to Keats, Pollock, Schoenberg, and Carroll. These men, it might be said, were great artists. It makes sense to cite their work as "unquestionably shielded" because their work is unquestionably great and hence of great value.

This "high value" thinking is perfectly logical, but it implies that the products of lesser poets or artists-Matthew Arnold, perhaps-might not be "unquestionably" shielded. Outright failures would seemingly, at least in principle, be subject to state prohibition. Judges, juries, or an expert agency could separate the wheat from the chaff. Again, there is nothing incoherent in this line of thinking, but it envisions a free speech jurisprudence foreign to American law.

Why does American law rebel at state aesthetic censors? Someone might try to explain this result without sacrificing the idea that art deserves protection because of its high potential value. We would not tolerate state boards of aesthetic review, this argument would run, because of the possibility that ignorant or middlebrow state actors would make fateful aesthetic mistakes. A society with state control over art might never have known Pollock's great abstractions, Schoenberg's tone poems, or Carroll's captivating Jabberwocky.

It is just here that the idea of "futilities" becomes crucial. 
To say that the freedom of speech protects "wholly neutral futilities" "as fully" as it protects Keats is to break with the whole enterprise of trying to justify First Amendment protection on the basis of the value of a given work. If the First Amendment protects futilities as fully as it protects Keats, then the protectedness of such speech does not depend on its aesthetic, political, or individual value, but on something else entirely.

What is a "futility"? There is more than one kind. Britney Spears is a futility. It is simply confusion to think that constitutional protection of her product depends on the quality of her singing or dancing, or on the possibility that those who disparage her talents are mistaken, or on the fact that she actually spurs a great deal of conversation on "matters of public concern." Britney Spears is constitutionally protected regardless of her talent and regardless of what people say about her.

Once we see this, however, it becomes apparent that not only the concept of "great art" is to be jettisoned here, but the whole constellation of concepts surrounding the word "art" itself. It is not as if the First Amendment centrally protects "art," as opposed to mere entertainment. The art/entertainment distinction has no place in First Amendment law. ${ }^{124}$ The freedom of speech fully protects J.K. Rowling whether her works count as junk, art, both, or neither.

It would be better, then, when we think about the constitutional status of poems, novels, songs, performances, paintings, and so on, to dispense with the idea that the First Amendment specially protects art. It would be better to dispense with the idea that the First Amendment protects works of high aesthetic, cultural, political, or individually-expressive value. We should say rather that the First Amendment protects-the freedom of imagination.

124. "[M]uch of today's high culture began as popular entertainment . . . . The practical effect of letting judges play art critic and censor would be to enforce conventional notions of 'educated taste,' and thus to allow highly educated people to consume erotica but forbid hoi polloi to do the same." Miller v. Civil City of S. Bend, 904 F.2d 1081, 1098 (7th Cir. 1990) (Posner, J., concurring), rev'd sub nom. Barnes v. Glen Theatre, Inc., 501 U.S. 560 (1991); see also Schad v. Borough of Mount Ephraim, 452 U.S. 61, 65-66 (1981) (striking down prohibition of live entertainment, stating that "[e]ntertainment, as well as political and ideological speech, is protected; motion pictures, programs broadcast by radio and television, and live entertainment, such as musical and dramatic works, fall within the First Amendment guarantee"); Salem Inn, Inc. v. Frank, 501 F.2d 18, 21 n.31 (2d Cir. 1974) (Oakes, J.) ("[W]hile the entertainment afforded by a nude ballet at Lincoln Center to those who can pay the price may differ vastly . . in quality (as viewed by critics), it may not differ in substance from the dance viewed by the person who ... wants some "entertainment' with his beer."), modified sub nom. Doran v. Salem Inn, Inc., 422 U.S. 922 (1975). 


\section{The Freedom of Imagination}

Imagination ought to be free. This should be First Amendment bedrock: No one may be penalized for what he dares to imagine. What a person can imagine, he may imagine.

But what is imagination, and what is its relationship to speech?

\section{Defining Imagination}

Imagination comes in many forms: intellectual, visual, emotional, musical, and so on. There are probably as many forms of imagination as there are forms of apprehending the world. To define is to confine, and imagination resists confinement.

But if we want to unite the various forms of imagination under one heading, we might begin by saying that to imagine is to conceive what isn't there. To imagine is to form an idea that goes beyond-that introduces something new to - what the mind has heretofore seen, heard, thought, or otherwise sensed. Imagination is the faculty by which the mind presents to itself what isn't actually present and what has never been actually present to it. $^{125}$

This faculty is exercised in two different but equally important ways. The first is creative. If I invent a story, I exercise my imagination creatively. Feeling, in the most capacious sense of the term, seems to actuate the creative imagination, in that people seem to imagine things in response to feelings they have about what is or might or ought to be in the world.

Imagination, we might say, is feeling mediated by idea.

The second way imagination is exercised is communicative. If I read your novel, I exercise my imagination through, and in response to, your communication. I imagine the story you wrote. Creativity is of course in

125. $C f$. Gaston Bachelard, ON Poetic Imagination and ReVerie 19 (Colette Gaudin trans., 1971) (explaining that imagination is "the faculty of deforming the images offered by perception, of freeing ourselves from the immediate images; it is especially the faculty of changing images"); IRIS MARION YOUNG, JUSTICE AND THE POLITICS OF DIFFERENCE 6 (1990) ("Imagination is the faculty of transforming the experience of what is into a projection of what could be, the faculty that frees thought to form ideals and norms."). To think of imagination this way is of course to accept a basic distinction between the real and the imaginary, which a postmodem or perhaps even a pragmatist sensibility would want to interrogate. See, e.g., Thomas C. Grey, Hear the Other Side: Wallace Stevens and Pragmatist Legal Theory, 63 S. CAL. L. REV. $1569,1572-75$ (1990) (discussing the "imagination-reality distinction"). But the distinction is indispensable; a postmodernist would already have accepted it the moment he said that reality is "really" inseparable from imagination. Roberto Unger may have best captured the relationship between reality and imagination: "You understand a portion of reality by passing it, in fact or fantasy, through transformative variations: by imagining it other than what it is or seems to be." ROBERTO MANGABEIRA UNGER, SOCIAL THEORY: ITS SITUATION AND ITS TASK 30 (1987). 
play when someone reads, just as authors are responding to others' communications when they invent stories. But typically the reader deploys much less creative imagination than the writer. A pianist or an actor sits between these two poles, exercising a good deal of imagination both creatively and communicatively at once.

The more sensorily complete a communication is, the less creative its recipient's imagination needs to be. A movie requires of its audience less creative imagination than does a novel, and virtual reality may leave nothing to the creative imagination at all. But movies and virtual reality still immerse their audiences deeply into the exercise of imagination because they present or represent to their audiences what is not actually present.

The freedom of imagination means the freedom to explore the world not present, creatively and communicatively. It means the freedom to see the world feelingly, to conceive as far as one is able how the world might be, or might have been, or could never be. It means the freedom to explore the entire universe of feeling-mediated-by-ideas. It means the freedom to explore, without state penalty, any thought, any image, any emotion, any melody, as far as the imagining mind may take it. Thus are works of artincluding nonverbal art--"unquestionably shielded."

So defined, the freedom of imagination calls into play-for constitutional purposes-no distinction between high value and low value; between art and entertainment; or between great, good, and bad. I assume there is a difference between a Caravaggio and a Britney Spears video: a difference in kind, not merely of degree. But for constitutional purposes, there is no difference between them, at least in the sense that both are exercises of the imagination, and both, therefore, equally enjoy full First Amendment protection.

Nor does the freedom of imagination distinguish between what artists do and what audiences do. Both artist and audience are engaged, directly, in exploring the imagination. Because it protects the freedom of imagination, the First Amendment directly protects not only speakers, but readers, viewers, and listeners as well.

But what is the purpose of protecting the freedom of imagination? Why should the First Amendment be read to guarantee it? The answer is twofold.

First, the freedom of imagination should be understood as central to the First Amendment if, as I hope, this freedom best captures the First Amendment's protection of art. In twenty-first century America, the freedom of speech undoubtedly means, among other things, that government cannot ban Keats or Pollock. Given that the First Amendment does not protect all words, and given that Pollock offers no words at all, we are obliged to ask what it is that makes Keats and Pollock unquestionably protected. 
In trying to answer that question, certain evident facts and difficulties have to be dealt with: that judges are not art critics, that even art critics cannot say what is art and what is not, ${ }^{126}$ and that the First Amendment applies to the reading of a poem as directly as it does to the writing of it. Responding to these facts and difficulties, yet also avoiding the twin pitfalls of false politicization and narcissism, the freedom of imagination is intended to explain the unquestioned protectedness of art. It is intended to do so, moreover, while simultaneously explaining why the First Amendment applies to creators, performers, and audiences alike, and why it makes no distinctions between high and low culture.

Second, and still more important, the freedom of imagination responds to what we might call the First Amendment's foundational paradigm cases. If the First Amendment means anything, it means that state actors cannot jail a person for holding the wrong political opinion or for believing in the wrong god. These protections are also protections of the imagination. To conceive of a god, or of a political state of affairs different from our own, is to imagine.

At root, the freedom of imagination rests on the same foundation as the First Amendment's core protections: a commitment that government shall not have power over what we think, that government cannot enforce an orthodoxy on any matter of opinion, that in America no one can be punished for daring to conceive or to express an unauthorized idea.

\section{Protecting the Imagination}

What would judges have to hold if they were to protect the freedom of imagination? How would this freedom be articulated into doctrine? To protect the freedom of imagination means courts must hold that there is no such thing as a harmful exercise of the imagination, constitutionally speaking.

126. This is an embarrassment that repeatedly led twentieth-century art theory to the proposition that art is whatever artists or the "art world" says it is. "A work of art ... is (1) an artifact (2) ... which has had conferred upon it the status of candidate for appreciation by some person or persons acting on behalf of a certain social institution (the artworld)." GEORGE DICKIE, ART AND THE AESTHETIC: AN INSTITUTIONAL ANALYSIS 34 (1974). "A work of art is a tautology in that it is a presentation of the artist's intention, that is, he is saying that that particular work of art is art, which means, is a definition of art." Joseph Kosuth, Art After Philosophy I and II, in IDEA ART 70, 83 (Gregory Battcock ed., 1973). De Duve summarizes the "current view" or "worse, the current convention" as follows: "Within the artworld it is understood that artists can do what they want, use any material to say whatever they want, respect or manhandle their technique, cultivate or transgress any available style, and they are accountable only to themselves" or "that they are dialectically accountable to the artworld for relentlessly criticizing it from within." DE DUVE, supra note 121, at 460 . All of which ought to make one wonder how we have identified who the "artists" are, or what the "art world" is, in the first place. 
In reality, of course, imagination can do all sorts of harm-as can equality, the right against self-incrimination, or anything else the Constitution protects. The First Amendment is not a nursery rhyme, insisting that words can never harm us. $A$ 's spoken imaginings may offend $B$. They may lead $C$ to think less well of $D$. They may lead $E$ to commit a crime. They may lead $F$ and $G$ into moral depravity. Or they may lead an entire country to adopt misguided policies.

Nevertheless, the freedom of imagination means that the state cannot restrict the imagination on the basis of these very real possible harms. Causing psychic harm to $A$ by deliberately running over $B$ can be a legally cognizable injury, but causing psychic harm to $A$ by performing The Merchant of Venice cannot be. Causing $A$ to commit a crime by paying him money can be a legally cognizable harm, but causing $A$ to commit the same crime by showing him a movie about American racism cannot be.

It will be objected that every action expresses imagination. A murder can be very creative. Perhaps the murderer was even "exploring" his imagination by killing his victim. If law cannot recognize harms arising from the imagination, it will be said, a creative murderer would have to go free.

But this objection is like saying that the First Amendment does not really protect political opinion because a person can go to jail if he expresses his political opinions by car bombing the White House. Yes, the car bomber can be prosecuted-but not for the opinion his conduct expressed. The car bomber can be prosecuted for assault, attempted murder, and so on, as long as he is prosecuted without reference to what he was trying to communicate through his actions. ${ }^{127}$

The freedom to express your political opinion does not mean that you have a right to express your opinion through any conduct you like. It does mean, however, that you cannot be punished for the opinion you communicated. "[N]onverbal expressive activity can be banned because of the action it entails, but not because of the ideas it expresses." ${ }^{128}$ The same is true of the freedom of imagination. This freedom does not mean that you have a right to exercise your imagination in any way you like. It means that you cannot be punished for exercising your imagination.

This point may seem tricky to some readers, but it is not complicated. Because it is essential to the analysis that follows, I want to be clear about it before proceeding.

127. See R.A.V. v. City of St. Paul, 505 U.S. 377,385 (1992) (explaining that "burning a flag in violation of an ordinance against outdoor fires could be punishable, whereas burning a flag in violation of an ordinance against dishonoring the flag is not").

128. Id. 
The question of what a person is punished for is central to all free speech law. Nearly any action we engage in is or can be communicative. Why, then, doesn't every law raise First Amendment problems? If a "performance artist" chooses to "express himself" by driving at sixty miles per hour on a fifty-five mile-per-hour highway, why doesn't he have a First Amendment defense to his prosecution?

There are several ways of answering this question; all but one of them are unsatisfying. We might say that the artistic speeder lacked a "particularized message," 129 but this answer would prove far too much. Most art has no such message. We might say that speeding is essentially "action" or "conduct," rather than "expression," 130 but trying to decide whether a given action is conduct or expression is famously unhelpful when the action is both conduct and expression. ${ }^{131}$ We could say that the "costs" of this expressive activity "exceed" its "benefits," 132 but this cost-benefit approach would not appeal to us at all if the state targeted communication directly. If a state banned Mapplethorpe because millions found his work offensive, we wouldn't try to quantify the benefits of Mapplethorpe's expression and then decide whether these benefits were high enough to "outweigh" the offense he produced.

The simpler and superior explanation is that a speed limit is not directed at communication. An artistic speeder may have been communicating something (or trying to) through his conduct, but whatever he was communicating is totally irrelevant to his liability for speeding. In the language used earlier, an individual arrested for speeding, no matter how expressively, is not made liable for speaking. He is guilty of speeding regardless of anything he might have been communicating thereby. ${ }^{133}$

How do we know when a person is punished for speaking? If the alleged harms that the state seeks to redress by prohibiting or prosecuting the conduct in question can be fully, persuasively explained without any reference to anything the person communicated through that conduct, then the person is not punished for speaking. This is true of speeding; it is also true of a murder prosecution. By contrast, when California prosecuted Cohen for wearing a jacket with the words "Fuck the Draft" on the back, the state's interest could not be explained without reference to what Cohen was saying. Whether the asserted harm lay in the offensiveness of the

129. Spence v. Washington, 418 U.S. 405, 411 (1974).

130. See THOMAS I. EMERSON, THE SYSTEM OF FREEDOM OF EXPRESSION 17 (1970).

131. See, e.g., John Hart Ely, Flag Desecration: A Case Study in the Roles of Categorization and Balancing in First Amendment Analysis, 88 HARV. L. REV. 1482, 1495 (1975).

132. See RICHARd A. POSNER, FrontIERS OF LEGAL THEORY 67 (2001) (offering a mathematical formula for determining when speech should be allowed based on a cost-benefit approach).

133. For more on all these points, see Rubenfeld, supra note 99 , at 776-78. 
words, an objection to his opinion, or the potential for a violent reaction, the harm to which California purported to be responding had to flow through individuals reading and understanding the words on Cohen's jacket. This idea is expressed in the case law whenever the Supreme Court states that where conduct is punished because of "harms distinct from" the conduct's "communicative impact," the conduct is "entitled to no constitutional protection." 134

The same reasoning applies to the freedom of imagination. A creative murderer may well be exercising his imagination, but to prosecute him is not to punish him for what he dared to imagine. The harm is in the killing, regardless of anything the murderer may or may not have imagined. The defendant will be tried for committing murder, not for imagining it.

A law violates the freedom of imagination when the harm at which it is aimed: (1) consists solely of having imagined something, (2) arises in one way or another from communicating what one has imagined, or (3) arises in one way or another from being the audience of another's communication of his imagination. When state action can be fully, persuasively explained without reference to any of these three kinds of harm, the freedom of imagination is not infringed.

Now, only thought-crimes prohibit imagining per se, and pure thoughtcrimes are hard to find these days. A law forbidding belief in more than one god would create a thought-crime. (There has always been a question about whether the freedom of speech would prohibit pure thought-crimes. The answer given here is yes. The freedom of imagination protects not only what one says to others, but also what one says to oneself.) Far more common have been laws imputing harm to the communication of imaginings, on the ground that these communications are offensive, corrupting, productive of wrongdoing, immoral, or otherwise dangerous. Such laws are unconstitutional.

The harm of communicating imagination must be distinguished, however, from the harm of acting on the imagination. The freedom of imagination demands that people be free to exercise their imagination. It is not a freedom to do what one imagines.

Hence acts of violence, no matter how imaginative and no matter how communicative, can always be punished as assault, battery, homicide, and so on. Say $X$ wants to communicate to $Y$ how it feels to have a broken nose. $X$ can paint a picture, make a movie, or perhaps even compose a symphony. Another option: $X$ can break $Y$ 's nose. The last strategy might be the most effective, but $X$ 's prosecution for assault and battery will not offend the freedom of imagination. He will not be charged with merely imagining

134. Roberts v. United States Jaycees, 468 U.S. 609, 628 (1984). 
something, and he will be guilty regardless of what he was communicating. $X$ may be punished for doing what he imagined, so long as he is not punished merely for having imagined something or for communicating what he imagined.

Nor is $A$ 's "mental state" somehow off-limits because of the freedom of imagination. Criminal law does not become unconstitutional when it conditions liability on the defendant's mental state. A person punished for committing an action with intention (or with recklessness or negligence) is not punished for his imagination. To repeat: A person is punished for exercising the imagination when he is punished for imagining per se, for communicating his imaginings to others, or for being the audience to another's imaginings. To be punished for acting with the intent to injure is not to be punished for any of these things.

\section{Imagination and Lying}

It is useful to situate imagination in relation to misrepresentation. A host of laws regulate false statements: not only libel, but fraud, perjury, false advertising, false labeling, Rule $10(b)(5)$ of the federal securities regulations, ${ }^{135}$ and so on. In general, the First Amendment allows the prohibition of falsehood. Why?

The Supreme Court's answer is that there is "no constitutional value in false statements of fact." ${ }^{\prime \prime 36}$ If not wholly conclusory, this proposition is something of a trick, suppressing a host of genuinely difficult First Amendment tangles. The freedom of imagination offers a better answer.

Consider the logic of the claim that false statements of fact have no constitutional value. Scientists today believe that photons are "particles." You can read this proposition in any number of books; presumably these statements are constitutionally protected. But the proposition may be false. Say that we discover its falsity tomorrow. Does this mean that, tomorrow, we should reflect back on today's state of affairs and say that "photons are particles" mistakenly enjoyed constitutional protection (because, as a false statement of fact, it never really had any "constitutional value")?

Putting things that way is unappealing. Surely it is not a constitutional mistake to protect scientists' right to state the facts as current science sees them. So it seems we would have to say that "photons are particles" has constitutional value today, but will cease to have such value if and when it proves mistaken. But then we would have conceded that false statements of

135. 17 C.F.R. $\S 240.10 b-5$ (2001).

136. Gertz v. Robert Welch, Inc., 418 U.S. 323, 340 (1974). 
fact can have considerable constitutional value-so long as their falsity is not yet known.

But once the claim is modified this way, new problems arise. Does an act of perjury enjoy constitutional protection provided that the falsity of the testimony is not known at the time and cannot then be proved? If we said so, we would be suggesting that the perjurer could not be prosecuted when his perjury later comes to light, because at the time he committed perjury, his statements still had "constitutional value."

This convoluted reasoning all proceeds from trying to work through the claim that there is "no constitutional value in false statements of fact." The truth is that falsehoods can have tremendous value, not only to those who propound them, but to those who believe them. They can be reassuring, consoling, inspiring, legitimizing. To say that false statements of fact have no "constitutional value" suggests that the only value the First Amendment recognizes is truth. If this were so, then all the other values falsehoods serve could indeed be ignored for constitutional purposes. But the First Amendment recognizes many other forms of value besides that of factual truth. Otherwise there would be no constitutional protection for a great deal of art. The First Amendment undoubtedly protects a wide variety of entertainment, and at an absolute minimum, false statements of fact can be very entertaining.

Suppose I believe that "God exists" is a false statement of fact. Am I therefore committed to the view that this statement has "no constitutional value"? I hope not. If I were a judge, hearing a case of a philosopher charged with "asserting the existence of moral facts," would I have to decide that "moral facts exist" was not a false statement of fact in order to dismiss the prosecution as unconstitutional? And how would I decide that?

The freedom of imagination avoids these difficulties because it rejects the claim that false statements have no constitutional value. Imagination is often expressed in false statements. Some novels consist of nothing but false statements of fact. The freedom of imagination's basic answer to the problem of misrepresentation is very different. Its answer is simple-if anything, too simple.

Imagining $X$ having an affair with $Y$ is not the same as asserting that $X$ had an affair with $Y$. On the contrary, " $X$ had sex with $Y$ " precisely claims that $X$ 's sexual relations with $Y$ are something other, something more, than an exercise of the imagination. (It claims that $X$ really did have sex with $Y$.) A lie is an exercise of imagination that denies or conceals its own imaginariness.

A liar says something imaginary but at the same time says, "This is not my imagination; this is how things actually are." Knowingly concealing his exercise of imagination, he forfeits his claim to its privileges. 
When the law penalizes knowing falsehoods, it does not target a harm imputed to the exercise of imagination. On the contrary, it targets the harm of knowingly denying that an exercise of imagination is an exercise of imagination. It targets just that element of the speech act that knowingly denies its own imaginativeness.

A free imagination is at liberty both to imagine the world however it can and to put its imagination into words. A free imagination is at perfect liberty to say: "Here is the world I have imagined." It is not free to assert that its imaginings are not imaginings when it knows otherwise.

This way of thinking explains why novels are constitutionally protected, even though they are filled with false statements of fact. The answer is not because novels, unlike false statements of fact, have "constitutional value"- which would be a purely conclusory answer, with no explanatory value-but because the fictitious statements in novels are not held out as statements of fact. Why is this decisive? The reason is that a fictitious statement held out as fiction does not deny its own imaginariness. By contrast, banning a novel on the ground that it consisted of nothing but false statements of fact would be perfectly intelligible if false statements of fact really had no constitutional value.

Some exercises of imagination, however, are not counterfactual. They concern the world as it actually is. When we say: "Yes, I imagine that's what happened," we don't mean that we are imagining a counterfactual. We mean that we are drawing inferences from what we know and, on that basis, forming a conjecture or speculation about something we don't.

The freedom of imagination therefore includes a freedom to wonder, to draw inferences, to reason, to speculate about the world. Contrary to the Supreme Court's dictum that false statements of fact have no constitutional value, exercises in speculation can be fully protected by the First Amendment even though they are false as a matter of fact. There is a perfect First Amendment freedom to suppose that the Central Intelligence Agency was a conspirator in President John F. Kennedy's assassination, even assuming this supposition is wrong as a matter of fact. Through the freedom of imagination, the First Amendment secures a freedom to speculate, even to speculate wrongly, about the truth.

This freedom is complete if the statement is held out to others as an act of speculation or of questioning. No one in the United States can be penalized for wondering whether something might be true. The freedom is limited, however, when conjectures are held out as nonconjectural.

This way of approaching the problem of false statements offers a better framework within which to understand the Supreme Court's rule that states cannot impose strict liability regimes (liability without fault) on libel 
defendants, even when the libel victim is a private figure. ${ }^{137}$ If false statements of fact "have no constitutional value," it is a little hard to understand why liability without fault for misrepresentation is so problematic that it must be barred altogether. But from the viewpoint of the freedom of imagination, strict liability for falsehood would indeed be problematic. Even a ban on reckless or negligent falsehood leaves room for the freedom to speculate, but strict liability for falsehood would eviscerate that freedom. Imagine a law under which a scientist who on good information today declared that photons are particles could be sued upon proof tomorrow that photons were not really particles after all. ${ }^{138}$

And what of statements such as "God exists" or "moral facts exist"? Ultimately, it is not helpful to think of these statements, as current doctrine would have it, as deserving protection on the ground that they are not false statements of fact. Rather, these statements are constitutionally protected because, whether true or false, they are paradigmatic exercises of the freedom to speculate and thus of the freedom of imagination. Imagination must be most at liberty in the universe of ultimate meanings, values, and truths - those truths that can never actually be present to us, because their very point is to transcend or to get below what is actually present.

\section{E. Imagination and Commercial Speech}

"[P]urely commercial advertising" was once denied First Amendment protection altogether. ${ }^{139}$ Today, the Supreme Court says that "commercial speech" enjoys some but not full First Amendment protection. ${ }^{140}$ It appears that commercial speech is regarded as most entitled to constitutional respect when it communicates (truthful) information of value to consumers. ${ }^{141}$ "The First Amendment's concern for commercial speech is based on the informational function of advertising." "142 The reasoning behind the

137. See Gertz, 418 U.S. at 347.

138. A long line of case law dealing with "public welfare offenses" in commercial contexts comes close to permitting strict liability for falsehood. See, e.g., United States v. Dotterweich, 320 U.S. 277 (1943) (upholding a conviction for selling dangcrously misbranded pharmaceuticals). I discuss the imaginative aspects of commercial speech in the next section, see infra Section III.E, but strict regulations of factual misrepresentation on product labels do not seem to me plausibly regarded as penalties on the imagination-again, precisely because such misinformation on product labels is not held out as imaginative. At least this is true in cases like Dotterweich.

139. Valentine v. Chrestensen, 316 U.S. 52, 54 (1942).

140. See Lorillard Tobacco Co. v. Reilly, 533 U.S. 525, 555 (2001)

141. See, e.g., Edenfield v. Fane, 507 U.S. 761, 766 (1993) (describing "First Amendment coverage of commercial speech" as "designed to safeguard" socicty's "interests in broad access to complete and accurate commercial information"); Va. State Bd. of Pharmacy v. Va. Citizens Consumer Council, 425 U.S. 748, 764 (1976) (emphasizing consumers' and society's “interest in the free flow of commercial information").

142. Cent. Hudson Gas \& Elec. Corp. v. Pub. Serv. Comm'n, 447 U.S. 557, 563 (1980). 
commercial speech doctrine has never been clear, but the cases seem to reflect the notion that commercial speech is somehow less "valuable" than fully protected speech. ${ }^{143}$

The freedom of imagination rejects this way of thinking. In the first place, as we have seen, it calls into question the whole construct of "highvalue/low-value" protected speech. If "commercial speech" is less valuable and therefore less deserving of constitutional protection than political or religious speech, why isn't the judiciary obliged to decide the value of music videos or "video art" before granting them full constitutional protection? To say that "wholly neutral futilities" come under the First Amendment's protection "just as fully" as Keats's poems is to break decisively from high-value/low-value thinking.

Moreover, the freedom of imagination rejects the notion that advertisements deserve constitutional solicitude only to the extent that they provide useful, truthful information. Of course, I don't mean that government cannot regulate advertising when it contains false information. Rather, advertising demands the most constitutional protection when it is least informational.

The noninformational side of advertising is plainly an affair of the imagination. A commercial that seeks to associate plastic forks with the good life obviously attempts to work its audience's imagination. Advertising may be the quintessential abuse of our imaginative faculties, but there can be no doubt that it seeks to speak (and presumably does speak, in many cases) to the imagination of its audience.

The freedom of imagination implies cultural freedom. Culture, we might say, is a set of practices through which members of a society explore their imagination. Every object, to the extent it participates in culture, participates in the exercise of imagination.

Even a plastic fork is a cultural artifact, although it is one that has little communicative power. It embodies creative imagination because someone had to conceive an idea of it in order for it to be made. But it usually speaks to no one's imagination. Perhaps a plastic fork will spur a person to think of plastic food; that is about the extent of it. The deadening of imagination is typical of the objects of our culture, and the entire function of advertising is to beat this dead horse into life-to beat imagination into our dead or meaningless objects of consumption.

Advertising is, happily or not, a principal carrier of our culture. It is perhaps definitive of our culture. The freedom of imagination leaves state

143. See, e.g., Lorillard, 533 U.S. at 553 ("[T]he Court has afforded commercial speech a measure of First Amendment protection 'commensurate' with its position in relation to other constitutionally guaranteed expression." (citation omitted)); Bd. of Trs. of State Univ. of N.Y. v. Fox, 492 U.S. 469,475 (1989). 
actors fully authorized to regulate advertising for falsehood, ${ }^{144}$ and like every other First Amendment freedom, it leaves room for state actors to regulate speech directed at children. But for good or ill, the freedom of imagination is not consistent with treating advertisements as deserving of less than full constitutional protection.

\section{IMAGINATION AND COPYRIGHT}

\section{A. Piracy}

Return now to copyright. The freedom of imagination supports copyright's core prohibition: the prohibition of piracy, meaning an unauthorized duplication (and sale) of another's work. But it calls into question a good deal of copyright law outside this core. Specifically, it calls into question copyright's treatment of "derivative work."

In pirating Gone with the Wind, I exercise my imagination not at all. Writing Gone with the Wind, the author exercised her imagination. Reading it, I exercise my imagination. Reproducing it mechanically, I do not. When copyright law bars simple piracy, it does not punish infringers for exercising their imagination. It punishes them for failing to exercise their imagination - for failing to add any new imaginative content to the copied material.

Why is it constitutional to ban the pirating of others' work despite the First Amendment's general hostility to content-based speech restrictions? Is it because copyright is the least restrictive means of furthering "compelling state interests" and is therefore justified despite its transgression of First Amendment values?

No, it is because in cases of flat-out piracy, no one is penalized for exercising his imagination. Indeed, in pure piracy cases, copyright law is not based on the imaginative content of the activity prohibited, because the activity prohibited - pure copying - expresses no imagination whatsoever.

To be sure, from one point of view, it is perfectly proper to say that a law prohibiting piracy is content-based, because the criterion of prohibition is precisely the identity of content between the copyrighted and pirated works. But the freedom of imagination suggests a different way to understand whether a law is "content-based." The correct test would ask whether, in order to know if certain words violated a law, someone has to understand those words. If words can violate a law even if no one ever understood them (including the producer, the intended audience, and the person charged with determining whether the law has been violated), then

144. See supra Section III.D. 
the law does not turn on any exercise of imagination and is not contentbased.

Consider a noise limit. No one needs to understand any words in order to know whether a noise limit has been violated; that is why such a law is correctly regarded as content-neutral. Even though the use of words may violate a noise-limit law, the law can be applied without any understanding of the words. By contrast, to determine whether a book is "indecent," someone has to understand what it says (and hence be imaginatively moved thereby). Indecency is a content-based concept precisely because a factfinder who did not understand the words that had been uttered, and who could not base his judgment on the reaction of people who did understand them, could not tell whether these words were "indecent."

Returning to piracy: A person who understood none of the words at all could in theory tell that a pirated copy of Gone with the Wind was a pirated copy of Gone with the Wind. He need only compare the written characters on their respective pages. Someone who spoke no English or even a machine could in principle make this determination. In other words, perfect reproduction can be demonstrated without anyone understanding the speech in question. In this sense, copyright's core prohibition is not content-based.

Similarly, from the viewpoint of the freedom of imagination, an injunction against pure reproduction is not a prior restraint. A prior restraint keeps imagination shut up inside the head of the would-be speaker. An injunction against piracy does not. An injunction against the sale of pirated copies of Gone with the Wind leaves that book (and the act of imagination it embodies) fully publishable--indeed published.

As soon, however, as copyright's proscriptions extend beyond this core, pathologies begin. The moment a court must read and understand a new book in order to know if it is "substantially similar" to a copyrighted work, copyright law becomes content-based. As soon as copyright's injunctions apply not only to pirated copies of Gone with the Wind but to a very different novel called The Wind Done Gone, these injunctions become prior restraints. And by the time copyright's germinal prohibition has so multiplied that it prohibits all "derivative works," copyright's First Amendment immunity should be a thing of the past.

\section{B. Derivative Work}

\section{The Emergence of Derivative Works Rights}

Under the earliest copyright laws, both English and American, copying was understood in the literal sense of reproducing a published work. As noted above, early American copyright law did not apply to translations-- 
as the author of Uncle Tom's Cabin learned to her dismay. ${ }^{145}$ The "only property," said the court, "which the law gives to [the author], is the exclusive right to multiply the copies of that particular combination of characters" of which the text consists. ${ }^{146}$ "A translation may, in loose phraseology, be called a transcript or copy of her thoughts or conceptions, but in no correct sense can it be called a copy of her book." 147

In 1870, Congress amended the copyright statute to include "the right to dramatize or translate." 148 Thus, the development of "derivative rights" had begun, a development that would increase steadily over the next century until by 1978 , copyright holders had the exclusive right not only to "reproduce" the copyrighted work, ${ }^{149}$ but also to prepare any "derivative works based upon the copyrighted work."150 And "derivative work" had been defined in the most capacious possible way, including "translation, musical arrangement, dramatization, fictionalization, motion picture version, sound recording, art reproduction, abridgment, condensation, or any other form in which a work may be recast, transformed, or adapted." 151

\section{How Current Law Blurs the Distinction Between Reproductions and Derivative Works}

Contemporary copyright jurisprudence rarely distinguishes between reproductions and infringing derivative works. Under present law, the copyright owner's "reproduction right" (the exclusive right to reproduce) is viewed as already encompassing much of what would otherwise be covered by the "derivative works right" (the exclusive right to prepare derivative works). Indeed, it has been claimed that the derivative works right, expansive though it might seem, is "completely superfluous."152

This claim is an exaggeration, ${ }^{153}$ but a surprisingly modest one. The explanation is that, in the 100 -year period during which Congress added

145. Stowe v. Thomas, 23 F. Cas. 201 (C.C.E.D. Pa. 1835) (No. 13,514) (finding no infringement in the German translation of a copyrighted book).

146. Id. at 206.

147. Id. at 208 .

148. Act of July 8,1870 , ch. $230, \S 86,16$ Stat. 198,212 .

149. 17 U.S.C. $\S 106(1)(2000)$.

150. Id. § 106(2).

151. Id. $\S 101$ (emphasis added).

152. 2 NIMMER, supra note $58, \S 8.09[\mathrm{~A}]$, at $8-137$. Nimmer argues that the derivative works right is superfluous because whenever this right is infringed, "there is necessarily also an infringement of either the reproduction or performance rights." Id.; see also Alcatel USA, Inc. v. DGI Techs., Inc., 166 F.3d 772, 787 n.55 (5th Cir. 1999) (quoting Nimmer approvingly).

153. In at least one situation-when the defendant does not make a new copy of the plaintiff's work, but uses a purchased copy in a new way - courts have found a violation of the derivative works right even in the absence of a violation of the reproduction right. See, e.g., Mirage Editions, Inc. v. Albuquerque A.R.T. Co., 856 F.2d 1341, 1344 (9th Cir. 1988) (cutting 
more and more derivative works rights to the copyright statute, judges accomplished a similar result through expanded interpretations of piracy and of the reproduction right itself. Thus, in 1868, a well-known case found "piracy" in a new play that "appropriated" a recognizable "series of events" from a preexisting one. ${ }^{154}$ In 1911, the Supreme Court found "reproduction" in a movie, Ben Hur, that borrowed a number of elements from (but also added new elements to) a novel by the same name. ${ }^{155}$ Perhaps most fundamentally, in 1930, Judge Learned Hand, writing for the Second Circuit, held that characters could be protected by copyright "quite independently of the 'plot' proper." 156

Deeming component elements of a work, such as characters, "independently" copyrightable effectively transforms the reproduction right into a derivative works right. Any later work that makes new use of the component element-whether a character or, say, a frightful glove from a horror movie ${ }^{157}$-is potentially infringing, because it includes an unauthorized "reproduction" of that component element. Thus, what might more naturally be regarded as a derivative work will instead be regarded as a reproduction.

This reading of the reproduction right cuts against the grain of the copyright statute itself. Not only does it render the derivative works right almost "completely superfluous," but by the terms of the statute, the reproduction right is supposed to be violated only when an infringer reproduces "the copyrighted work," 158 and one might have thought that copying a character or glove was not the same as reproducing the copyrighted "work." But that is not how current case law interprets the statute. Today, the owner of the Superman copyright could win a suit for "character infringement" if a new film was guilty of "copying" the Superman character-i.e., if its protagonist was "substantially similar to" or "strongly resembled Superman"-even though the film told a new story,

out the plaintiff's art prints and gluing them to ceramic tiles violated derivative works rights even if it did not amount to "reproduction").

154. Daly v. Palmer, 6 F. Cas. 1132,1138 (C.C.S.D.N.Y 1868) (No. 3552) ("[l]t is a piracy, if the appropriated series of events, when represented on the stage, although performed by new and different characters, using different language, is recognized by the spectator ... as conveying substantially the same impressions to, and exciting the same emotions in, the mind, in the same sequence...."). The "appropriated... events" apparently involved only a single scene, which actually differed in a number of respects in the two works, in which a character tied to railroad tracks was saved at the last moment from an onrushing train. Paul Goldstein, Derivative Rights and Derivative Works in Copyright, 30 J. COPYRIGHT SOC'Y 209, 213-14 (1983).

155. Kalem Co. v. Harper Bros., 222 U.S. 55, 63 (1911) (calling the making of a motion picture version of a novel "a particular, cognate and well-known form of reproduction").

156. Nichols v. Universal Pictures Corp., 45 F.2d 119, 121 (2d Cir. 1930).

157. See New Line Cinema Corp. v. Easter Unlimited Inc., 17 U.S.P.Q.2d (BNA) 1631, 1633 (E.D.N.Y. 1989) (protecting the demonic glove from the Nightmare on Elm Street film series).

158. 17 U.S.C. $\$ 106(1)$ (2000) (emphasis added). 
used a different name for its protagonist, and gave him a "trait inconsistent with the traditional Superman image," for example "portray[ing] him in the service of the underworld." 159 A derivative works right is indeed superfluous when the reproduction right already covers derivative works.

In a sense, the reproduction right's transformation into a derivative works right was foreordained by the stunning decrease in the amount of copying that came to be required in literal reproduction cases. In the early period, when copyright protected only against reproduction, even an abridgment was not considered infringement. ${ }^{160}$ In other words, reproduction was understood as a copying of the entire work. Today, reproducing a minute or two from a film (in a television broadcast) ${ }^{161}$ or a few hundred words from a book (in a news article) ${ }^{162}$ is unquestionably enough to constitute infringement. Indeed, courts have occasionally found infringement in a single sentence. ${ }^{163}$ If you reproduce eight sentences from one of Martin Luther King's famous speeches, you certainly risk copyright liability. ${ }^{164}$ As the amount-copied requirement has dramatically diminished, the reproduction right has proportionately expanded, and in this way too it has metamorphosed into a derivative works right.

159. Warner Bros. Inc. v. ABC, 720 F.2d 231, 239, 241, 243 (2d Cir. 1983). At first, some courts resisted the protection of characters precisely because it did not seem to make sense within a paradigm of infringement that looked to reproduction of the copyrighted "work" (as opposed to one of the elements making up that work). See, e.g., Warner Bros. Pictures, Inc. v. CBS, 216 F.2d 945, 950 (9th Cir. 1954) (denying copyright protection to Dashiell Hammett's Sam Spade and suggesting that reproducing a character is not in itself a copyright infringement unless "the character really constitutes the story being told"). Today, however, the copyrightability of original, well-delineated characters is not seriously challenged. See, e.g., DC Comics, Inc. v. Reel Fantasy, Inc., 696 F.2d 24, 28 (2d Cir. 1982) (recognizing "property in the Batman character"); Walt Disney Prods. v. Air Pirates, 581 F.2d 751, 754-56 (9th Cir. 1978) (holding various Disney characters, including Mickey Mouse, protected); CBS v. DeCosta, 377 F.2d 315, 320 (1st Cir. 1967); Metro-Goldwyn-Mayer, Inc. v. Am. Honda Motor Co., 900 F. Supp. 1287, 1295-97 (C.D. Cal. 1995) (holding James Bond protected); see also 1 NIMMER, supra note 58, § 2.12, at 2-173 to -177 .

160. See, e.g., Lawrence v. Dana, 15 F. Cas. 26, 59 (C.C.D. Mass. 1869) (No. 8136).

161. See, e.g., Roy Exp. Co. v. CBS, 503 F. Supp. 1137 (S.D.N.Y. 1980), aff'd, 672 F.2d 1095 (2d Cir. 1982); Iowa State Univ. Research Found., Inc. v. ABC, 463 F. Supp. 902 (S.D.N.Y. 1978), aff d, 621 F.2d 57 (2d Cir. 1980).

162. See Harper \& Row, Publishers, Inc. v. Nation Enters., 471 U.S. 539, $548-49$ (1985) (holding that copying 300 words out of 200,000 is clcarly sufficient to infringe and too great to justify the fair use defense).

163. See, e.g., Universal City Studios, Inc. v. Kamar Indus., Inc., 217 U.S.P.Q. (BNA) 1162 (S.D. Tex. 1982) ("I love you E.T." and "E.T. Phone Home"); Dawn Assocs. v. Links, 203 U.S.P.Q. (BNA) 831 (N.D. Ill. 1978); see also Narell v. Freeman, 872 F.2d 907, 912 (9th Cir. 1989) (suggesting that quoting the first two lines of a poem would infringe); Am. Greetings Corp. v. Kleinfab Corp., 400 F. Supp. 228, 232-33 (S.D.N.Y. 1975) (holding copyrightable "Put on a Happy Face").

164. Martin Luther King, Jr. Ctr. for Soc. Change, Inc. v. Am. Heritage Prods., Inc., 508 F. Supp. 854, 860 n.3, 861 (N.D. Ga. 1981) (ordering impoundment of all copies of a pamphlet containing eight sentences from one King speech in addition to sentences from others), rev' $d$ on other grounds, 694 F.2d 674 (11 th Cir. 1983). 


\section{Constitutionalizing Copyright}

The key to a constitutional copyright law lies in reclaiming and narrowing the core concept of reproduction, thereby revitalizing the distinction between derivative works and reproduction.

Derivative works always bring with them a new injection of imagination. They therefore demand First Amendment protection. They cannot be prohibited, as a mere reproduction can. Under the analysis proposed here, no change in current copyright law would have to be made concerning run-of-the-mill copyright piracy, but significant changes would have to be made to copyright law as it applies to derivative works. Although copyright law can continue to confer special derivative works rights on authors, new rules-detailed below-would have to limit the available remedies, just as the First Amendment has been held to require special remedy rules in libel law.

Even the most faithful film version of a novel cannot be produced without substantial imagination: in the visualization of place, the realization of character, and so on. The same is true of the most pedestrian sequel to a novel. And a "sequel" like The Wind Done Gone turns the entire imaginative world of the original upside down (the whites turn out to be black; the blacks turn out to be in control; and what was good, true, and beautiful in the original turns out to be bad, false, and ugly in the "sequel").

Therefore, as applied to derivative works, prepublication injunctions are prior restraints. The injunction necessarily suppresses a new act of imagination. Having expanded to cover all "derivative works based upon the copyrighted work," copyright law today vests in a single party the power to engage in content-based and even viewpoint-discriminatory suppression of speech everywhere-in public, on the Internet, in a book, or in a theater. This result is constitutionally unacceptable.

When a derivative work is suppressed, what is the harm against which the law protects? There are two possible answers. The first invokes copyright's economic rationale, claiming that unauthorized derivative works impede the production of creative work (on the nonobvious ground that more creative work will be produced overall if authors have exclusive derivative works rights). ${ }^{165}$ The second answer sounds in the property

165. Early law-and-economists purported to find economic justifications for the derivative works right, see, e.g., William M. Landes \& Richard A. Posner, An Economic Analysis of Copyright Law, 18 J. LEGAL STUD. 325, 354-55 (1989), but closer analysis has forcefully questioned these justifications, see Mark A. Lemley, The Economics of Improvement in Intellectual Property Law, 75 TEX. L. REV. 989, 1046-72, 1074-77 (1997); Glynn Lunney, Jr., Reexamining Copyright's Incentives-Access Paradigm, 49 VAND. L. REV. 483, 599-656 (1996) (arguing on efficiency grounds that copyright law should prohibit only duplication); Stewart E. Sterk, Rhetoric and Reality in Copyright Law, 94 MlCH. L. REV. 1197, 1217 (1996) ("The broad 
intuition; the claim here is that allowing unauthorized derivative works would contravene authors' rights to determine the fate of their creations. This seems to have been the view of the district court in the Wind Done Gone case:

When the reader of Gone With the Wind turns over the last page, he may well wonder what becomes of Ms. Mitchell's beloved characters and their romantic, but tragic, world. Ms. Randall has offered her vision of how to answer those unanswered questions .... The right to answer those questions ...., however, legally belongs to Ms. Mitchell's heirs, not Ms. Randall. ${ }^{166}$

So unauthorized derivative works might be deemed harmful because they (1) upset the incentives necessary to maximize production of valuable speech and (2) violate authors' moral rights. But even if these harms were real they could not justify suppression. Unlike literal copying, derivative works always involve a fresh exercise of imagination. Whether the asserted harms are economic or moral, the ultimate source of these putative harms is necessarily an act of imagination. The claim is that allowing others freely to imagine their own visualizations or continuations of an author's story, and to communicate these imaginings to others, will produce legally cognizable harms.: But under the First Amendment, there can be no such thing as a harmful exercise of the imagination.

No court in the United States should need to wrestle through a set of complicated statutory factors (the factors of the fair use defense) before deciding whether to suppress a book like The Wind Done Gone. We don't suppress books in this country. Courts have no authority to suppress a book on the ground that its exercise of imagination is harmful and unauthorized. To do so violates the First Amendment - period.

How should copyright judges distinguish between reproductions and derivative works? Current doctrine already provides an answer. In cases where an author has created a derivative work based not on copyrighted materials, but on public domain materials, courts are obliged to decide whether the new work is sufficiently original to support a copyright of its

protection copyright doctrine extends to derivative works . . . appears generally inconsistent with the incentive justification for copyright.'). Landes and Posner, supra, had suggested that the derivative works right reduces transaction costs because it allowed makers of derivative work to negotiate with only a single party. As Sterk pointed out, however, eliminating the derivative works right would reduce transaction costs still more, freeing makers of derivative work from negotiation altogether. Sterk, supra, at 1217.

166. SunTrust Bank v. Houghton Mifflin Co., 136 F. Supp. 2d 1357, 1384 (N.D. Ga.), vacated, 252 F.3d 1165 (11 th Cir.) (per curiam), order vacated and opinion substituted, 268 F.3d 1257 (11th Cir. 2001). 
own. ${ }^{167}$ The Supreme Court has expressly ruled that investing mere labor or money in a new work is insufficient; some form of "creativity" must be added. ${ }^{168}$ The required quantum of creativity is not large; any "substantial" or "distinguishable variation" from the preexisting work will be sufficient. ${ }^{169}$

Before the reproduction right metamorphosed into a derivative works right, a later work that creatively transformed preexisting materials was understood to fall outside the prohibition of the reproduction right. This view should be reaffirmed today. So holding would be fully consistent with the copyright statute, which distinguishes categorically between reproductions and derivative works. It is the case law, not the statute, that has run the two together.

To be sure, not just any change in the original work should suffice to evade the copyright holder's reproduction right. Trivial or obvious modifications, or changes that involve no substantially new act of imagination, especially if introduced to evade the reproduction right, should not qualify. At bottom, the judge is called on to decide whether the old has been reimagined-whether the allegedly infringing new work is in fact new.

The First Amendment consequences of this determination are as follows. If the later work merely pirates the older work, it can be enjoined, and damages can be awarded. If it is not a reproduction but a derivative work, neither an injunction nor damages should be available. In such cases, however, the copyright holder would not be left wholly without remedy. Instead, he would have an action for profit allocation.

Nothing in the First Amendment stands in the way of requiring that profits from a derivative work (if any) be apportioned to the copyright holder to the extent that those profits are justly attributable to the appropriated material. Current copyright law cannot reach this result. Consider the Supreme Court's 2 Live Crew case, which held that a rap spinoff of Oh Pretty Woman was a parody of the original and therefore potentially a fair use. ${ }^{170}$

The fair use determination functions here as an on-off determinant of liability. If 2 Live Crew's Pretty Woman was a fair use of the preexisting

167. Under 17 U.S.C. $\$ 103$ (a) (2000), derivative works based on public domain materials are copyrightable. A work will not qualify for copyright protection, however, unless it consists of "editorial revisions, annotations, elaborations, or other modifications which, as a whole, represent an original work of authorship." $1 d$ d. 101.

168. Feist Publ'ns, Inc. v. Rural Tel. Serv. Co., 499 U.S. 340, 344 (1991).

169. See, e.g., Matthew Bender \& Co. v. W. Publ'g Co., 158 F.3d 674, 680 (2d Cir. 1998); Norma Ribbon \& Trimming, Inc. v. Little, 51 F.3d 45, 47 (5th Cir. 1995); 1 NIMMER, supra note $58, \S 3.03[\mathrm{~A}]$, at 3-12.

170. Campbell v. Acuff-Rose Music, Inc., 510 U.S. 569 (1994). The Court remanded for further consideration of the market-substitution factor. Id. at 593-94. 
Oh Pretty Woman - a determination said to turn largely on whether the new song was "transformative" of the old, both creatively and for purposes of the market-substitution analysis ${ }^{171}$ - then the new song was totally outside the prohibitions of copyright law, leaving the copyright holder with no claim at all. Conversely, if Pretty Woman was not fair use, then the copyright holder could receive not only damages, but in principle injunctive relief as well.

From a First Amendment perspective, this is a doubly wrong result. Pretty Woman was not the same song as Oh Pretty Woman. It was plainly "transformative," having not only new lyrics but a completely different sound and feel. ${ }^{172}$ Hip-hop "sampling" generates new music; that is its virtue. It also steals; that is its vice. Because it was new music, 2 Live Crew's Pretty Woman should have been categorically protected from an injunction, regardless of whether it "criticized" the original. ${ }^{173}$ But there is no reason why 2 Live Crew was entitled to reap all the profits from its transformative use of Oh Pretty Woman, when some of those profits were unquestionably attributable to Roy Orbison's immensely popular tune. ${ }^{174}$

The remedy rule I am suggesting does not track the Calabresi-Melamud distinction between "property rules" (which permit injunctions where the property owner does not consent to the taking of his property) and "liability rules" (which permit damages, but not injunctions). From the perspective of the freedom of imagination, if a new work is new enough to be constitutionally non-enjoinable, it is equally immune from injunctions and damages.

A damages action is just another way of enforcing legally cognizable injury, and as I have said, copyright law cannot constitutionally recognize

171. Id. at 579,591. The Court derived the "transformative use" test from Leval, supra note 69. The Court gives no indication that it obtained consent to this derivative use of Leval's article from the copyright owner.

172. The transformativeness test makes the fair use doctrine strangely track the statutory test for derivative works, which are defined, inter alia, as works that have "transformed" a preexisting work. 17 U.S.C. $\S 101$.

173. Under current law, if a derivative work is found not to be a parody or other form of fair use, it can be enjoined. See, e.g., Dr. Seuss Enters. v. Penguin Books USA, Inc., 109 F.3d 1394 (9th Cir. 1997).

174. Actions for profit allocation already have a basis in current copyright doctrine, so the proposal made here does not call on courts to oversee an unknown form of action. See 17 U.S.C. $\S 504$ (b) (providing for recovery, by the copyright owner, of "any profits of the infringer that are attributable to the infringement"). The statute divides the burden of proof as follows: "In establishing the infringer's profits, the copyright owner is required to present proof only of the infringer's gross revenue, and the infringer is required to prove his or her deductible expenses and the elements of profit attributable to factors other than the copyrighted work." Id. For a leading case under the 1909 statute, involving an action for apportionment of profits from a movie based, without authorization, on a copyrighted play, see Sheldon v. Metro-Goldwyn Pictures Corp., 309 U.S. 390 (1940). In part because of this statutorily authorized cause of action, I refer throughout to "profits" and to actions for "profit allocation." But I do not mean to rule out an action based on revenues, rather than or as a measure of profits, in appropriate cases. 
as legally redressible the harm that a new exercise of imagination might do to the original author or to anyone else. In piracy cases, damages are perfectly appropriate, but in derivative works cases, a defendant is no more subject to damages than to an injunction. An action for profit allocation, however, is not a damages action.

A profit-allocation action does not suppress speech or impute harm to the exercise of imagination in the new work. It does not penalize the author for exercising or communicating his imagination. It does not penalize at all, leaving the author no worse off than he would have been had he chosen not to commercialize the derivative work. If the producer of a derivative work offers the work for free, he is immune from suit altogether. If, on the other hand, the appropriator seeks to profit from his appropriation, as he is free to $\mathrm{do}$, then he becomes liable to an action for profit allocation. ${ }^{175}$

The "performance right" currently guaranteed by copyright law ${ }^{176}$ would be subject to the same rules. Although the mere mechanical reproduction of a work is no exercise of the freedom of imagination, performing a work almost always is (or was, until "performance" was interpreted to refer to such activities as the screening of a film ${ }^{177}$ ). This is obviously so when musicians perform a symphony or actors a play, but it is no less true when a person "performs" a poem by reciting it. Live performances of copyrighted work, therefore, should be immune from injunctions or damages. But if money is made from such a performance, the copyright holder could have a claim to apportionment. ${ }^{178}$

In fact, copyright law already adopts a somewhat similar approach for certain songs and other musical works through the "compulsory license"

175. For a good discussion and defense of a profit-allocation regime for derivative works, see Alex Kozinski \& Christopher Newman, What's So Fair About Fair Use?, 46 J. CoPYRIGHT SOC'Y 513, 525-26 (1999). Kozinski and Newman, however, propose their remedy rules as a replacement for current fair use doctrine. See id. I am not suggesting that the action for profit allocation replace the fair use doctrine. The argument here is that the regime of injunctions and damages for derivative works is unconstitutional, so that an action for profit allocation is the most that the copyright owner can have. Thus, the fair use doctrine is not directly affected by the analysis here. The fair use defense is a statutorily codified further protection of a special subset of derivative works (those that make "fair use" of the copyrighted work); these fair-use works are not actionable at all. This complete insulation from liability might in theory be constitutionally required in some instances (such as news reporting), but it might violate the First Amendment in others (as a form of viewpoint-discrimination, see supra text accompanying notes 21-24, 76-79). I leave the constitutional dimensions of fair use doctrine open for further study.

176. See 17 U.S.C. $\$ 106(4)$.

177. See id. (including "motion pictures" in the list of works to which the performance right applies); id. $\S 106(6)$ (referring to the right to "perform" "sound recordings" "by means of a digital audio transmission"). Only the actual performing of a work, as opposed to the replaying of a performance captured on film or $C D$, requires imagination.

178. Even under current law, a number of exceptions to the performance right are made for nonprofit institutions and uses. See id. $§ 110$. 
system. ${ }^{179}$ The perverse feature of the current system is that the more transformative the performance, the more likely a finding of infringement becomes. ${ }^{180}$ In addition, the compulsory license does not include the right to perform the work live in public. ${ }^{181}$ Finally, compulsory licensing in its current form is not the same as profit allocation; on the contrary, the fee must be paid regardless of revenues. A compulsory license might be one way to operationalize a remedy regime of the sort I am proposing - in which copyright holders have no right to injunctive relief, but are entitled to a just apportionment of profits-but the current scheme would have to be altered dramatically in order to satisfy the First Amendment's requirements.

In sum, I have argued that the First Amendment requires special remedy rules for copyright holders' derivative works rights and performance rights. These rights can still be vindicated, but only by actions for apportionment of profits - a proposal that might have serious consequences for the economics of the entertainment industry. For example, there would no longer be "exclusive movie rights" to a novel or play as we know such rights today. Anyone would be legally free to make a film from a Harry Potter book or the musical West Side Story, just as under current law anyone can make a film of a Jane Austen novel or a Shakespeare play.

With this difference: An unauthorized film of a copyrighted work would be subject to an action for profit allocation. Apportioning profits in such cases would not be an obvious proposition; the share of profits owing to the original author might be very considerable. So there would be a form of valuable "movie rights" after all: the right to make the film version of a book without being subject to a profit allocation suit. Needless to say, parties would be wise to negotiate such rights in advance. It is conceivable that this legal state of affairs might result, in some or many cases, in production practices not too different from the existing ones.

I make no claim about whether this result would be good or bad policy. The result is not supposed to follow from policy considerations. It is supposed to follow from constitutional considerations: Current copyright law is unconstitutional in that it permits courts to issue injunctions or grant damages in cases of derivative works and live performances. With respect

179. The owner of a copyright in a nondramatic musical work in U.S. distribution is compelled to permit others to make and sell new recordings of the copyrighted music (using their own musicians, engineers, and so on) in exchange for royalties. Id. $\S 115$.

180. The licensee has a right to vary the music "to suit his own style and interpretation," Stratchborneo v. Arc Music Corp., 357 F. Supp. 1393, 1405 (S.D.N.Y. 1973), but not to "change the basic melody or fundamental character of the work," 17 U.S.C. $\$ 115(\mathrm{a})(2)$. It was because of this provision that 2 Live Crew's Pretty Woman was not covered by the compulsory license. See Campbell v. Acuff-Rose Music, Inc., 510 U.S. 569, 574 n.4 (1994).

181. E.g., Irving Berlin, Inc. v. Daigle, 31 F.2d 832 (5th Cir. 1929) (decided under the 1909 copyright statute). 
to derivative works and performances, copyrights act as prior restraints. They create a private power over public speech that is unacceptable and tantamount to censorship. They penalize the exercise of the imagination.

Perhaps, however, these conclusions are too large to expect courts to adopt them. ${ }^{182}$ Consider this Article, then, an exercise in imagination. But be advised that no one may publish any works derivative of it without permission of the copyright holder.

\section{CONCLUSION}

Copyright is today in the same position, vis-à-vis the First Amendment, as libel was before New York Times v. Sullivan. Just as the Court in Sullivan finally began issuing a set of special constitutional rules confining the reach of libel law, so the courts must eventually do for copyright. In the elaboration of these rules, the freedom of imagination ought to play the same role for copyright that the freedom of "wide-open and robust debate" has played for libel. ${ }^{183}$

The freedom of imagination extends far beyond art and entertainment. Philosophy is an exercise of the imagination too. So is prayer. So is a call for political change. The freedom of imagination, in other words, protects "core" First Amendment speech just as it protects novels or pictures. It does so not because imagination informs voting, nor because imagination is central to individual autonomy. It does so because the freedom of imagination articulates the First Amendment's core commitment: that no

182. As I write these words, the Supreme Court has granted certiorari in the case in which the Court of Appeals for the District of Columbia Circuit announced that copyrights "are categorically immune from challenges under the First Amendment." Eldred v. Reno, 239 F.3d 372, 375 (D.C. Cir. 2001), cert. granted sub nom. Eldred v. Ashcroft, 122 S. Ct. 1062 (2002). Eldred concerns the constitutionality of retroactively extending the duration of copyrights; it is conceivable but unlikely that the Court will use Eldred to change the basic terms of copyright's relationship to the First Amendment. The question is more likely to be whether a retroactive extension of preexisting copyrights, at least to the enormous lengths now conferred, can rationally be thought to promote the government's legitimate interest in stimulating the production of valuable work. According to the analysis developed in this Article, this is a question of copyright's economic justifiability, most properly raised, not under the First Amendment, but under the language of the exclusive rights clause of Article I, which allows Congress to grant copyrights "for limited Times" to "promote the Progress of Science and useful Arts." See Section II.C (distinguishing economic analysis of copyright from First Amendment analysis). But the analysis developed here could assist the Court in Eldred, if, for example, the Court were to recognize that copyright law, insofar as it applies to anything other than pure duplication, is a content-based speech restriction, penalizing persons for exercising their imagination, and therefore requiring some kind of heightened First Amendment scrutiny.

183. See Phila. Newspapers Inc. v. Hepps, 475 U.S. 767, 772 (1986); N.Y. Times Co. v. Sullivan, 376 U.S. 254, 270 (1964) (recognizing "a profound national commitment to the principle that debate on public issues should be uninhibited, robust, and wide-open"), quoted in, e.g., Milkovich v. Lorain Journal Co., 497 U.S. 1, 20 (1990). 
one may be legally punished for thinking an unauthorized thought or for expressing an unauthorized idea. 